\title{
Polar marine biology science in Portugal and Spain: Recent advances and future perspectives
}

José C. Xavier ${ }^{\text {a,b,* }}$, Andrés Barbosa ${ }^{\text {c }}$, Susana Agustí d,e,f ${ }^{\text {, Laura Alonso-Sáez }}{ }^{\mathrm{g}}$, Pedro Alvito ${ }^{\mathrm{a}}$, Julia Ameneiro ${ }^{\mathrm{h}}$, Conxita Ávila ${ }^{\mathrm{i}, \mathrm{j}}$, Alexandra Baeta ${ }^{\mathrm{a}}$, João Canário ${ }^{\mathrm{k}}$, Raquel Carmona ${ }^{\mathrm{l}}$, Paulo Catry ${ }^{\mathrm{m}}$, Filipe Ceia ${ }^{\mathrm{a}}$, Melody S. Clark ${ }^{\mathrm{b}}$, Francisco J. Cristobo ${ }^{\mathrm{n}}$, Bruno Cruz ${ }^{\mathrm{a}}$, Carlos M. Duarte ${ }^{\mathrm{d}, \mathrm{e}, \mathrm{f}}$, Blanca Figuerola ${ }^{\mathrm{i}, \mathrm{j}}$, Josep-Maria Gili ${ }^{g}$, Ana R. Gonçalves ${ }^{a}$, Francisco J.L. Gordillo ${ }^{1}$, José P. Granadeiro ${ }^{\circ}$, Miguel Guerreiro ${ }^{\text {a }}$, Enrique Isla $^{\mathrm{g}}$, Carlos Jiménez ${ }^{1}$, Pablo J. López-González ${ }^{\mathrm{p}}$, Sílvia Lourenço ${ }^{\mathrm{a}, \mathrm{q}}$, João C. Marques ${ }^{\mathrm{a}}$, Elena Moreira ${ }^{\text {, }}$, Ana M. Mota ${ }^{\mathrm{r}}$, Marta Nogueira ${ }^{\mathrm{k}}$, Laura Núñez-Pons ${ }^{\mathrm{i}}$, Covadonga Orejas ${ }^{\mathrm{s}}$, Vitor H. Paiva ${ }^{\mathrm{a}}$, Albert Palanques ${ }^{\mathrm{g}}$, Gareth A. Pearson ${ }^{\mathrm{t}}$, Carlos Pedrós-Alió ${ }^{\mathrm{g}}$, Álvaro L. Peña Cantero ${ }^{\mathrm{u}}$, Deborah M. Power ${ }^{\mathrm{t}}$, Jaime A. Ramos ${ }^{a}$, Sergi Rossi ${ }^{\mathrm{v}}$, José Seco ${ }^{a}$, Elisabet Sañé ${ }^{\mathrm{g}}$, Ester A. Serrão ${ }^{\mathrm{t}}$, Sergi Taboada ${ }^{\mathrm{i}}$, Sílvia Tavares ${ }^{\mathrm{w}}$, Núria Teixidó $^{\mathrm{g}}$, Dolors Vaqué ${ }^{\mathrm{g}}$, Tiago Valente ${ }^{\mathrm{a}}$, Elsa Vázquez ${ }^{\mathrm{h}}$, Rui P. Vieira ${ }^{\mathrm{a}, \mathrm{o}, \mathrm{x}}$, Benjamin Viñegla ${ }^{\mathrm{y}}$

a Institute of Marine Research (IMAR-CMA), Dept. of Life Sciences, University of Coimbra, 3001-401 Coimbra, Portugal

b British Antarctic Survey, NERC, High Cross, Madingley Road, CB3 OET Cambridge, United Kingdom

c Departamento de Ecología Evolutiva, Museo Nacional Ciencias Naturales, CSIC, C/José Gutierrez Abascal, 2, 28006 Madrid, Spain

d Instituto Mediterráneo de Estudios Avanzados, IMEDEA (CSIC-UIB), Miquel Marqués, 21, 07190 Esporles, Mallorca, Spain

e The UWA Oceans Institute, The University of Western Australia, 35 Stirling Highway, 6009 Crawley, Australia

f School of Plant Biology, The University of Western Australia, 35 Stirling Highway, 6009 Crawley, Australia

${ }^{g}$ Institut de Ciències del Mar (CSIC), Pg. Marítim de la Barceloneta 37-49, 08003 Barcelona, Spain

h Departamento de Ecoloxía e Bioloxía Animal, Facultade de Ciencias do Mar, Universidade de Vigo, Campus de Lagoas-Marcosende, 36200 Vigo, Spain

i Departament de Biologia Animal (Invertebrats), Facultat de Biologia, Universitat de Barcelona, Av. Diagonal 643, 08028 Barcelona, Catalunya, Spain

j Biodiversity Research Institute (IrBIO), Av. Diagonal 643, 08028 Barcelona, Catalunya, Spain

k IPMA. I.P., Av. Brasília, 1449-006 Lisboa, Portugal

${ }^{1}$ Departamento de Ecología, Universidad de Málaga, Campus de Teatinos s/n, 29071 Málaga, Spain

m Eco-Ethology Research Unit, ISPA, Rua Jardim do Tabaco 34, 1149-041 Lisboa, Portugal

${ }^{n}$ Centro Oceanográfico de Gijón, Instituto Español de Oceanografía (IEO), Av. Príncipe de Asturias 70 bis, 33212 Gijón, Asturias, Spain

- CESAM, University of Aveiro, Campus Universitário de Santiago, 3810-193 Aveiro, Portugal

p Departamento de Fisiología y Zoología, Facultad de Biología, Universidad de Sevilla, Reina Mercedes 6, 41012 Sevilla, Spain

q Centro de Oceanografia, Laboratório Marítimo da Guia, Faculdade de Ciências, Universidade de Lisboa, Avenida Nossa Senhora do Cabo 939, 2750-374 Cascais, Portugal

${ }^{\mathrm{r}}$ Centro de Química Estrutural (CQE), Instituto Superior Técnico, Universidade Técnica de Lisboa, Av. Rovisco Pais, 1049-001 Lisboa, Portugal

${ }^{s}$ Instituto Español de Oceanografía, Centro Oceanográfico de Baleares, Moll de Ponent s/n, 07015 Palma de Mallorca, Spain

${ }^{\mathrm{t}}$ Centre of Marine Sciences (CCMAR), University of Algarve, Campus of Gambelas, 8005-139 Faro, Portugal

u Instituto Cavanilles de Biodiversidad y Biología Evolutiva, Universidad de Valencia, C/Catedrático José Beltrán, 2, 46980 Paterna, Valencia, Spain

` Institut de Ciencia i Tecnologia Ambientals-Universitat Autónoma de Barcelona, UAB Campus Cn s/n, Cerdanyola del Vallès 08193, Spain

${ }^{w}$ Centre for Functional Ecology, Department of Life Sciences, University of Coimbra, PO Box 3046, 3001-401 Coimbra, Portugal

x Department of Biology, University of Aveiro, Campus Universitário de Santiago, 3810-193 Aveiro, Portugal

y Departamento de Biología Animal, Biología Vegetal y Ecología, Universidad de Jaén, Campus Las Lagunillas s/n., 23071 Jaén, Spain

\section{A R T I C L E I N F O}

\section{Article history:}

Received 17 December 2012

Received in revised form 24 May 2013

Accepted 25 May 2013

Available online 14 June 2013

\section{A B S T R A C T}

Polar marine ecosystems have global ecological and economic importance because of their unique biodiversity and their major role in climate processes and commercial fisheries, among others. Portugal and Spain have been highly active in a wide range of disciplines in marine biology of the Antarctic and the Arctic. The main aim of this paper is to provide a synopsis of some of the results and initiatives undertaken by Portuguese and Spanish polar teams within the field of marine sciences, particularly on benthic and pelagic biodiversity (species diversity and abundance, including microbial, molecular, physiological and chemical mechanisms

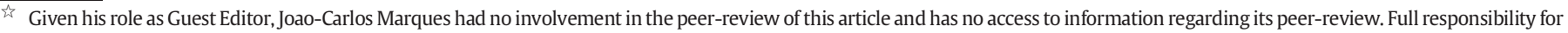
the editorial process for this article was delegated to Angel Borja.

* Corresponding author at: Institute of Marine Research (IMAR-CMA), Dept. of Life Sciences, University of Coimbra, $3001-401$ Coimbra, Portugal. Tel.: + 351 936728419.

E-mail address: jccx@cantab.net (J.C. Xavier).
} 
Keywords:

Polar science

Arctic

Antarctic

Marine biology

Portugal

Spain in polar organisms), conservation and ecology of top predators (particularly penguins, albatrosses and seals), and pollutants and evolution of marine organisms associated with major issues such as climate change, ocean acidification and UV radiation effects. Both countries have focused their polar research more in the Antarctic than in the Arctic. Portugal and Spain should encourage research groups to continue increasing their collaborations with other countries and develop multi-disciplinary research projects, as well as to maintain highly active memberships within major organizations, such as the Scientific Committee for Antarctic Research (SCAR), the International Arctic Science Council (IASC) and the Association of Polar Early Career Scientists (APECS), and in international research projects.

\section{Contents}

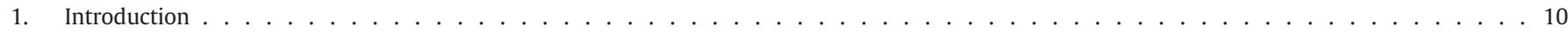

2. Dynamics of the Antarctic marine food web: the role of top predator-prey interactions in a climate change context - José Xavier, Sílvia Lourenço, Filipe Ceia, Bruno Cruz, José Seco, Rui Vieira, Miguel Guerreiro, Pedro Alvito, Ana Rita Gonçalves, Sara Pedro, Tiago Valente, Sílvia Tavares, Vitor Paiva, Alexandra Baeta, Jaime Ramos and João Carlos Marques ． . . . . . . . . . . . . . . . . . . . . . . . . . 11

3. Contaminant, carbon, nutrient fate and biogeochemistry in polar regions - João Canário, Marta Nogueira and Ana Maria Mota . . . . . . . . . 11

4. Ecological studies of black-browed albatrosses on the Falkland Islands - Paulo Catry and José Pedro Granadeiro . . . . . . . . . . . . . . . . 12

5. Understanding shell secretion in bivalve molluscs: the Antarctic clam Laternula elliptica as a model species - Melody Clark and Deborah Power . . . 14

6. Microbial plankton during the Arctic winter - Carlos Pedrós-Alió and Laura Alonso-Sáez . . . . . . . . . . . . . . . . . . . . . . . . . . . 14

7. Effects of global warming and ice melting on the microbial food web in polar regions: thresholds of sustainability - Dolors Vaqué, Susana Agustí, Ester

Serrão, Gareth Pearson and Carlos M. Duarte ～. . . . . . . . . . . . . . . . . . . . . . . . . . 14

8. Distribution of meroplankton in West Antarctica - Elsa Vázquez and Julia Ameneiro . . . . . . . . . . . . . . . . . . . . . . . . 17

9. Pelagic-benthic coupling over the Antarctic continental shelf - Enrique Isla, Elisabet Sañé, Josep-Maria Gili, Sergi Rossi, Albert Palanques . . . . . . 17

10. Biodiversity of high Antarctic marine benthic biota - Josep-Maria Gili, Pablo J. López-González, Núria Teixidó and Codavonga Orejas . . . . . . 19

11. Biodiversity, ecology, biogeography and evolution of the Antarctic benthic hydroids - Álvaro L. Peña Cantero . . . . . . . . . . . . . . . . . 20

12. The ACTIQUIM project: chemical and biological diversity in the Southern Ocean - Conxita Ávila, Francisco J. Cristobo, Laura Nuñez-Pons, Sergi Taboada,

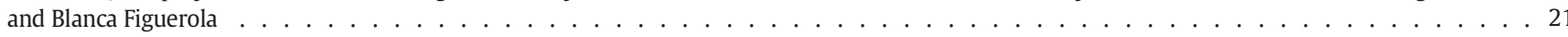

13. Effect of ocean acidification, temperature and UV radiation in polar seaweeds - Francisco J. L. Gordillo, Elena Moreira, Benjamín Viñegla, Raquel Carmona and Carlos Jiménez . . . . . . . . . . . . . . . . . . . . . . . . . . . . . . . . . . . . . . . . 22

14. Penguins as sentinels of Antarctic Marine Ecosystem: global change effects - Andrés Barbosa . . . . . . . . . . . . . . . . . . . . . . 23

15. Final considerations and future perspectives . . . . . . . . . . . . . . . . . . . . . . . . . . . . . . 24

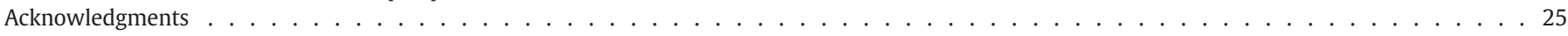

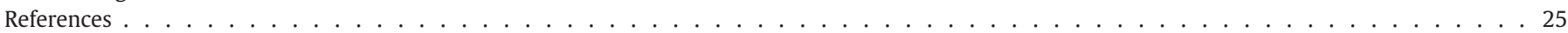

\section{Introduction}

Major scientific investigations have been carried out in the polar regions, including those related to marine sciences on which this review is centered, by scientists from more than 60 countries worldwide, in the last 200 years (Krupnik et al., 2011). The Southern Ocean and the Arctic Ocean play unique and critical roles for both the physical Earth system and its overall ecology by both strongly influencing the climate and harboring unique and diverse biological communities (ACIA, 2005; Turner et al., 2009). Portugal and Spain have been very active in carrying out studies related to polar science in the last two to three decades, particularly in the Antarctic region (Xavier et al., 2006b).

As a new country carrying out polar research, Portugal was highlighted as a successful example of a recent emergent polar nation during the International Polar Year (Schiermeier, 2009). Portuguese researchers have been regularly involved in polar science, mainly in the Antarctic, through other countries' national programs (Xavier et al., 2006b). In the last 10 years, the number of Portuguese researchers has increased considerably, especially due to the impetus of the International Polar Year. Portugal defined a strategy for polar science in 2006 (Xavier et al., 2006b) and established a successful scientific research program, PROPOLAR, and an educational program, LATITUDE60! (Kaiser et al., 2010). Portugal also joined several major polar organizations, including the Scientific Committee for Antarctic Research (SCAR) in 2006, the Association of Polar Early Career Scientists (APECS) and the European Polar Board (EPB) in 2007, signed the Antarctic Treaty in 2010 and has been involved in major polar research and outreach outputs (Baeseman et al., 2011; Zicus et al., 2011). Portuguese scientists have been awarded some of the most important polar research awards nationally and internationally (e.g. Marta T. Muse prize from the Tinker Foundation).
Marine biology research by Portuguese scientists in the polar regions started with Luiz Saldanha in the 1970s/1980s via collaboration with the French Antarctic program (Ré et al., 2001; Saldanha, 1983, 1991; Saldanha et al., 1990a,b). This pioneering example was followed by Antarctic research from teams from the University of the Azores, ISPA - Instituto Universitário, the Centre of Marine Sciences of the University of Algarve (Xavier et al., 2006b), IPMA and the Institute of Marine Research of the University of Coimbra, among others, working particularly with UK, France, Norway and Canada (see below).

Marine biology research could also potentially be considered as the origin of the Spanish polar research activity. In the austral summer of 1986-1987, the first scientific expedition in Antarctica was organized by the Spanish Institute of Oceanography (IEO) using two fishing vessels, the Nuevo Alcocero and the Pescapuerta IV, to study marine Antarctic species and their potential for commercial fisheries. In 1986, the first field camp was also established on Livingston Island to preliminary map where the future Spanish Antarctic base Juan Carlos I would be located. At the same time, several marine biology studies were carried out. These activities were the result of previous scientific work carried out sporadically by some researchers, which contributed to Spain being integrated into different international organizations (see below). Dr. A. Ballester and Dr. J. Castellvi from the Marine Fisheries Institute (Spanish Research Council) played a key role in this initiative. In 1982, Spain became an observer member of the Antarctic Treaty, integrating its consultative board in 1988. In 1987, Spain became an associate member of the Scientific Committee on Antarctic Research (SCAR) and was admitted as a full member in 1990. Spain has also recently been admitted as an observer member of the Arctic Council (in 2006) and of the International Arctic Science Council (IASC, in 2009).

More than twenty years later, Spanish polar research, specifically polar marine biology, has matured and expanded as evidenced by Spain's 
major participation in the International Polar Year (2007-2008). Currently, there are more than 9 groups working in different aspects of polar marine biology, most of them are included in the present review (see below), but there are still considerable challenges in the future (Benayas et al., 2011). The collaboration between Spain and Portugal in polar research started in the late 1990s with projects on cryosphere and climate change (Xavier et al., 2006b). In recent years, the collaboration has increased considerably with more groups working together, many of which carry out research on marine biology (see below).

The following sections provide a synopsis of some of the important results and initiatives undertaken by Portuguese and Spanish polar teams in the field of marine sciences. These overviews are designed to provide background information on the work carried out by both countries as well as providing examples of the research already developed.

\section{Dynamics of the Antarctic marine food web: the role of top pred- ator-prey interactions in a climate change context - José Xavier, Sílvia Lourenço, Filipe Ceia, Bruno Cruz, José Seco, Rui Vieira, Miguel Guerreiro, Pedro Alvito, Ana Rita Gonçalves, Sara Pedro, Tiago Valente, Sílvia Tavares, Vitor Paiva, Alexandra Baeta, Jaime Ramos and João Carlos Marques}

In order to understand how marine food webs in the Southern Ocean are related to environmental change, the research group at the Institute of Marine Research of the University of Coimbra (Portugal) focuses on testing relevant hypotheses on top predator-prey interactions by gathering essential biological data on all trophic levels as well as behavioral, foraging and feeding studies on key top predator species (e.g. albatrosses, seals and penguins). Their multi-disciplinary research projects bring together scientists from more than 10 countries, particularly from Portugal, UK and France. This work was started in 1997 at the British Antarctic Survey and co-sponsored by the Fundação para a Ciência e a Tecnologia (Portugal) under various programs (e.g. Portugal Polar Program PROPOLAR, POLAR, CEPH, PENGUIN, BAS-PSPE), being one of the most productive collaborations. Indeed, both organizations have written a memorandum of understanding to reinforce and promote polar research collaborations. Work with Spain has been mostly on the feeding and foraging ecology of penguins, with Dr. Andrés Barbosa.

The main outputs of our projects have provided valuable data on the feeding ecology of top predators (Ceia et al., 2012; Xavier and Croxall, 2005, 2007; Xavier et al., 2003b,c; Xavier et al., 2013), prey biology and distribution (Collins et al., 2012; Collins et al., 2008; Roberts et al., 2011; Xavier et al., 2002a,b; Xavier et al., 1999), the use of stable isotopic signature techniques (Guerreiro, Alvito et al., unpublished data), methods developed to identify predators' diet (Xavier and Cherel, 2009; Xavier et al., 2005; Xavier et al., 2007a; Xavier et al., 2011b), fisheries assessment and management (Pilling et al., 2001; Xavier et al., 2007b), albatross conservation (Xavier et al., 2004), heavy metals on Antarctic food webs (Tavares et al., in press) and food web modeling (Xavier et al., 2006a; Xavier et al., 2007b). Results from this research have been integrated into international science and policy programs, such as ICED (Integrating Climate and Ecosystem Dynamics of the Southern Ocean), CAML (Census of Antarctic Marine Life), ACAP (Agreement for the Conservation of Albatrosses and Petrels), SCAR AnT-ERA (Antarctic Tresholds, ecosystem resilience and adaptation) and SCAR-EBA (Evolution and Biodiversity of the Antarctic Scientific Committee for Antarctic Research). Furthermore, our research group is highly engaged in science communication, capacity building, education and outreach at national and international levels, in collaboration with APECS (Baeseman et al., 2011), SCAR Capacity Building, Education and Training group and Polar Educators International (PEI).

Within top predator-prey interactions in the Southern Ocean, seabirds are among the major consumers and albatrosses are threatened by conflict with fisheries (competition for the same stocks of prey or incidental mortality) (Croxall et al., 1988; Croxall et al., 2012). Wandering albatrosses Diomedea exulans are classified as "Vulnerable" (i.e. facing a high risk of extinction in the wild in the medium-term) according to the
IUCN Red List of threatened species (Croxall and Gales, 1998) and are one of our most studied species.

Through satellite/GPS tracking and diet studies, the foraging and feeding behavior of wandering albatrosses from South Georgia and their interactions with fisheries during their chick-rearing period were analyzed (Xavier et al., 2003b,c; Xavier et al., 2004; Phillips et al., 2008). They feed mostly on fish and cephalopods. While breeding, they can cover 15,000 km in their foraging trips in Antarctic, sub-Antarctic and subtropical waters and overlap with long-line fisheries in three different areas around South Georgia, at the Patagonian shelf and in oceanic waters north of $40^{\circ} \mathrm{S}$ (Xavier et al., 2004). These results emphasized that inter-annual variation in the foraging preferences of wandering albatrosses could lead to increased incidental mortality of this albatross species. During their brood-guard period, the foraging areas and diets of wandering albatrosses can be complementary to those of gray-headed albatrosses Thalassarche chrysostoma; wandering albatrosses foraged at the South Georgia shelf (Antarctic waters) and Antarctic Polar Frontal Zone (APFZ) waters feeding on fish and cephalopods whereas gray-headed albatrosses foraged in shelf waters of the South Shetland Islands and Antarctic Peninsula and oceanic waters around South Georgia (Antarctic waters) feeding mainly on Antarctic krill Euphausia superba (Xavier et al., 2003c). The latter result was a reflection of the oceanographic conditions in the year the study was conducted (March/ April 2000), which were abnormally warmer close to South Georgia, and affected the foraging and feeding behavior of gray-headed albatrosses (Xavier et al., 2003c Xavier et al., 2013); usually, gray-headed albatrosses are known to feed mainly on cephalopods (Xavier et al., 2003a).

When comparing the inter-annual variations of the diets of gray-headed albatrosses with black-browed albatrosses Thalassarche melanophrys breeding at South Georgia, in relation to their breeding performance, our results showed that the consumption of the ommastrephid squid Martialia hyadesi was significantly and positively correlated with gray-headed albatross breeding success (Xavier et al., 2003a; Xavier et al., 2013). For black-browed albatrosses, significant correlations were found between its consumption of the icefish Champsocephalus gunnari and breeding success (Xavier et al., 2003a).

Linking foraging behavior and diets of top predators with prey abundance is not an easy task. To evaluate the biology and distribution of pelagic organisms (fish, cephalopods and crustaceans), our group has been involved in Antarctic research cruises since 2000 in performing work on the distribution of mychophid fish (Collins et al., 2012; Collins et al., 2008), toothfish (Pilling et al., 2001; Roberts et al., 2011) and cephalopods (British Antarctic Survey, unpublished data). Our understanding of the role of cephalopods in the Antarctic marine ecosystem is surprisingly poor (Collins and Rodhouse, 2006; Xavier et al., 2012a) despite occurring in the diet of a wide range of predators from the Southern Ocean, including whales, albatrosses, penguins and seals (comprehensive review in Xavier and Cherel, 2009). Moreover, cephalopods are among the few Antarctic fisheries still with potential to be exploited in the future (Xavier et al., 2007b). Our future studies aim to assess the role of cephalopods in the food web structure at different time scales (intra-, inter- and inter-decadal) across the Atlantic, Indian and Pacific sectors of the Southern Ocean by analyzing the stable isotopic ratios of carbon $\left({ }^{13} \mathrm{C}\right)$ and nitrogen $\left({ }^{15} \mathrm{~N}\right)$ from cephalopod beaks. This new technique has been applied in the Southern Ocean with great success (Ceia et al., 2012; Cherel and Hobson, 2005) and will provide a unique picture of the marine environment and trophic relationships and allow the development of new mathematical models of the Antarctic food web in different climatic and environmental scenarios.

\section{Contaminant, carbon, nutrient fate and biogeochemistry in} polar regions - João Canário, Marta Nogueira and Ana Maria Mota

The polar regions are recognized as being geopolitically and economically important and extremely vulnerable to current and projected 
climate change (Anisimov et al., 2007). It is likely that the physical changes already observed have altered carbon, nutrient and contaminant cycles through both biological and chemical mechanisms (Macdonnald et al., 2005). Since contaminants enter global systems through exchanges between air, water, and solids, the physical and chemical effects of those changes will clearly result in major climate interactions (Beyer and Matthies, 2001). The Portuguese research group on Environmental Chemistry has been working in this area since 2008 via collaborations between Dr. Laurier Poissant (Environment Canada) and the Portuguese PROPOLAR program. Three field campaigns have been carried out so far. Two of these were in the Canadian sub-Arctic (Kuujjuarapic-Whapmagoostui and Umiujaq) funded by IPY CiCAT and COBRA projects. The main goals were to study carbon, nutrient and contaminant fate, transport and speciation during ice melt season. The impact of the melting permafrost (e.g. thermo-karst ponds) on the surrounding aquatic ecosystems was also a key issue in the research goals of the group. In 2011, the team has also been involved in the Project CONTANTARC funded by the Fundação para Ciência e Tecnologia. The goals of CONTANTARC were similar to the above ones but the fieldwork took place on Deception Island at the Antarctic Peninsula. CONTANTARC 2 is now underway with a sampling campaign planned for the beginning of 2013 at King George Island also at the Antarctic Peninsula.

The research in the Canadian Arctic was conducted between 2008 and 2009. Water and sediment chemistry, atmospheric deposition and permafrost were the key research areas under investigation. The main focus centered on the processes wherein both carbon (organic and inorganic in particulate and dissolved form, methane and carbon dioxide) and nutrients (nitrate, ammonia, phosphate and silicate) behave and interact in the ecosystem due to the impact of climate change at different temporal and spatial scales. During the fieldwork, samples of air, water, ice, snow and sediments were collected in different aquatic ecosystems such as natural lakes, thermo-karst lakes, rivers and the sea, namely the Hudson Bay. Findings indicated that short variations in weather conditions influence the dynamics of the various fractions of both carbon and nutrients. Also the team of João Canário confirmed that thermo-karst lakes may contribute a significant source of carbon and nutrients to river watersheds by deposition of refractory organic material and also that they contribute to the emission of methane and/or carbon dioxide to the atmosphere. Interestingly, we found that the emission of methane or carbon dioxide is related to the water and sediment carbon content in those lakes.

Investigations into trace elements showed that arsenic, cadmium, chromium, copper, nickel, lead and uranium tend to accumulate on ice due to their affinity to/with organic matter (Canário, pers. observation). Enrichment factors $\left(C_{\text {ice }} / C_{\text {water }}\right)$ determined for these elements varied between $1.2(\mathrm{As})$ and $67(\mathrm{Cu})$. Based on these findings, we hypothesize that during an ice melt season, these contaminants will accumulate in the water column increasing their availability to aquatic organisms. To test this hypothesis, we sampled water from the Umiujaq River for 10 days at the same time as ice thickness was decreasing.
During the experiment, a big snowstorm occurred at day 5 and the melting process was inverted with the formation of new ice. Results showed that $\mathrm{Pb}$ concentrations increased in the water column during the ice melt, with the opposite trend during new ice formation (Fig. 1). Similar results were obtained for $\mathrm{Cu}, \mathrm{Zn}, \mathrm{Cd}, \mathrm{Cr}$, and As. This is of environmental concern because these contaminants would then become bio-available for living organisms during the springtime bloom (João Canário, unpublished data).

Results from our Antarctic work in Antarctica are still being analyzed. Fieldwork took place on the volcanic Deception Island, in the South Shetland Archipelago. Our aims were to understand the fate and biogeochemistry of trace elements in the austral ecosystems, in particular, to evaluate the role of organic carbon, which is very scarce in the south (DeMaster et al., 1991), and the importance of active volcanism as a source of trace elements to the ecosystem. Preliminary results indicate volcanism as a source of mercury and cadmium in the ecosystem. $\mathrm{Hg}$ and Cd concentrations were considerably higher near these volcanic hotspots compared to those obtained from other sites on the island and even higher compared to the contaminated Tagus Estuary (Canário et al., 2005; Vale et al., 2008). In Deception Island, trace element transport was not influenced by carbon content, as total organic carbon is considerably lower compared to the Arctic samplings and not correlated with trace element distribution.

\section{Ecological studies of black-browed albatrosses on the Falkland Islands - Paulo Catry and José Pedro Granadeiro}

The Patagonian Shelf is one of the most productive marine regions on the planet. This area supports a rich community of top predators, including many subantarctic marine birds and mammals, some of which reproduce locally (Falabella et al., 2009). In terms of biomass, blackbrowed albatrosses T. melanophrys are one of the most important avian species in this region, with the numbers nesting in the Falkland Islands representing ca $70 \%$ of the global population of this seabird.

Albatrosses are pelagic seabirds and are one of the bird families with a high proportion of species classified as threatened on the IUCN Red List. Among the main threats to albatrosses worldwide, incidental mortality linked to industrial fisheries (both in long-lines and in trawlers) currently seems to be the most important. Other relevant issues include large-scale ecosystem changes resulting from global warming and overfishing, the presence of introduced predators on nesting islands, the spread of diseases and pollution. The black-browed albatross is currently classified as endangered at a global scale, although this may need revision in light of recent data.

The first partial census of the Falklands population of black-browed albatrosses took place in the 1980s, and some ecological studies were then started, but until recently, very little information was known regarding the demography of this population. In 2003, the first longterm demographic study of black-browed albatrosses in the Falklands was initiated by the team of Paulo Catry. The research is based on New Island (a private reserve) and financial support has been obtained
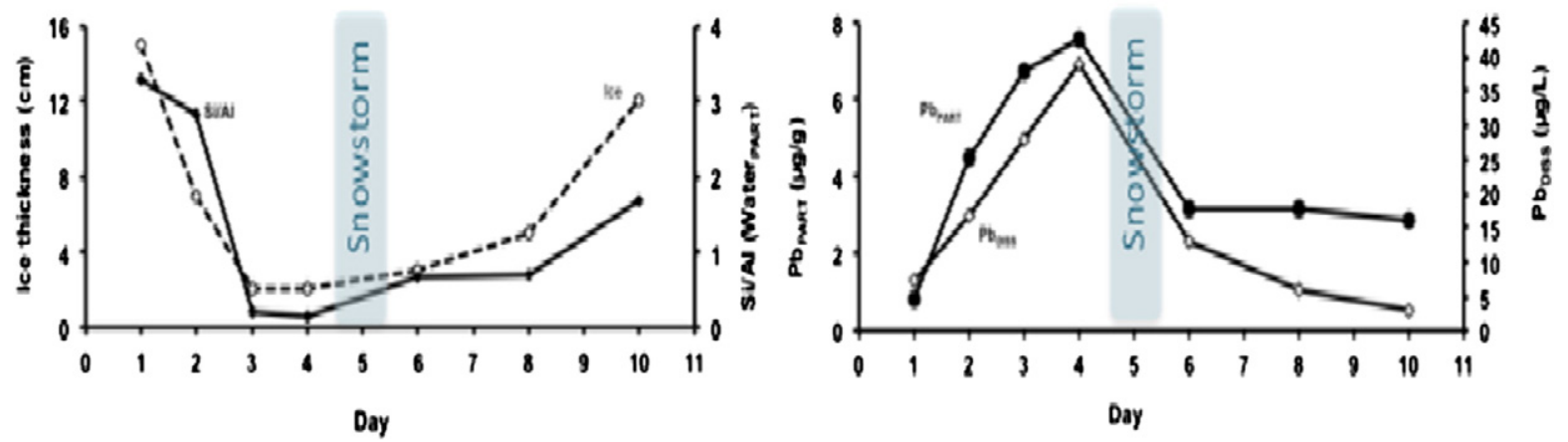

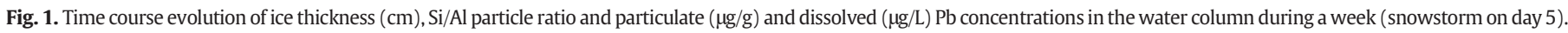


mostly from the Falkland Islands Government, the New Island Conservation Trust and Fundação para a Ciência e a Tecnologia (Portugal).

Catry's team has a permanent sample of over 500 individually marked albatrosses whose fate is followed year after year, including information on their survival, incidence of breeding, partnerships, and several breeding parameters. All individuals recruited into the study areas are also ringed. Chicks at the colony are ringed annually and many have already returned and started breeding. Using these data, the first estimates of survival and breeding success for the Falkland Island breeding albatrosses have been recently published (Catry et al., 2011b). Results were striking, with a high annual adult survival, a low incidence of breeding deferral and good breeding success. This was the first clear indication that the Falkland albatrosses are going through a period of positive demographic trend, while they were previously believed to be in trouble with a rapid population decline. These results suggest that efforts made by Falkland Islands authorities and those of neighboring countries with the goal of reducing albatross incidental mortality in fishing gears are producing the desired results.

While conducting our long-term demography study, Paulo Catry's team also focused on many other aspects of the ecology of blackbrowed albatrosses, as well as of their predators. Dietary studies of introduced cats and of striated caracaras Phalcoboenus australis suggest that neither is likely to pose a significant threat to albatrosses (Catry et al., 2008; Matias and Catry, 2008). Studies on skuas (Catry et al., 2011a) are still progressing, but clearly they can take a considerable number of albatross chicks in years when food is less plentiful. Studies of parasites (including ticks) and diseases are also underway. A contagious disease of still unknown etiology has been identified, and it can kill considerable numbers of chicks in some years (Matias and Catry, pers. observation). These studies, involving other components of the community (complemented by other fundamental research topics, e.g. in the field of behavioral ecology (Catry et al., 2010)), allow a better interpretation of the ecological and demographic data, and overall provide important insights into the state of the Patagonian Shelf ecosystem. In fact, seabirds such as black-browed albatrosses are increasingly used for marine monitoring and taken into account in plans for the ecosystem-based management of fisheries, in marine zoning and in the design of marine protected areas.

Currently, one of the main areas of research focuses on the study of interactions between albatrosses and fisheries. For this, this research team has been collaborating with the Falkland Islands Fisheries Department, who provide us with detailed Vessel Monitoring System data from the fishing fleet operating in the Falkland territorial waters. This, together with GPS tracking of birds, has allowed the study of interactions with a level of detail never achieved before (Granadeiro et al., 2011). Results were unexpected, suggesting a low level of dependence of albatrosses on fishery discards (Granadeiro et al., 2011) and also that the presence of the industrial fishing fleet has little influence on the distribution and habitat selection of albatrosses (Paulo Catry, pers. observation). Further work involves regular diet sampling using not only conventional methods but also stable isotope and genetic techniques to analyze dropping contents using barcoding methods. Research has also focused on investigating if individual birds tend to specialize on fishery products. First results indicate that this is not the case (Granadeiro and Catry, pers. observation).

Recently, we extended the scope of our research. Ecological studies are no longer confined to New Island albatrosses, and considerable efforts have been deployed in studying the at-sea distribution of albatrosses from Steeple Jason (Northwest Falklands), the world's largest colony for this species with ca 200,000 pairs (Fig. 2). Collaborations have been established with several international researchers, including members of CONICET (Consejo Nacional de Investigaciones Científicas y

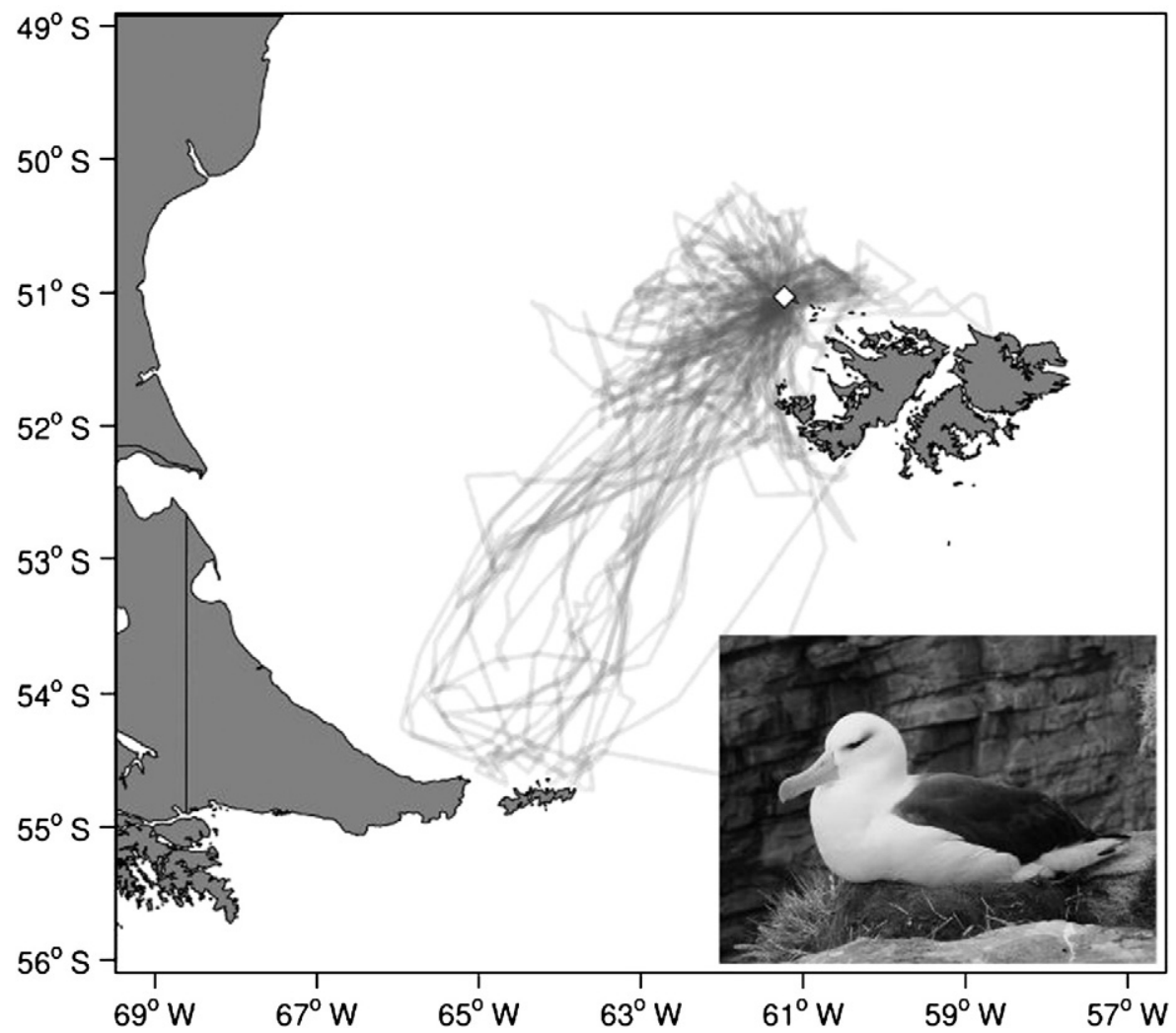

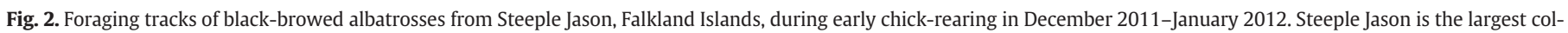
ony in the world for this species, with ca 200,000 pairs. 
Técnicas) in Argentina, which will allow a broadening of the scope of the work and access to detailed fishery data from the main country with jurisdiction over the Patagonian Shelf.

\section{Understanding shell secretion in bivalve molluscs: the Antarctic clam Laternula elliptica as a model species - Melody Clark and Deb- orah Power}

There is currently great concern over the acidification of the world's oceans and its marked potential and demonstrated effects on a wide range of life. In the 250 years since the onset of the industrial revolution, atmospheric $\mathrm{CO}_{2}$ levels have risen from 280 to $381 \mathrm{ppm}$ (Canadell et al., 2007) and ocean pH has fallen from an average of 8.16 to 8.05 (Caldeira and Wickett, 2003). Human-driven emissions of $\mathrm{CO}_{2}$ continue to rise at accelerating rates and have begun to outstrip even the most pessimistic of IPCC model scenarios (Canadell et al., 2007). The corresponding increase in uptake of $\mathrm{CO}_{2}$ by the ocean sinks form carbonic acid, reducing ocean $\mathrm{pH}$ and decreasing the saturation state of calcium carbonate. These changes in ocean $\mathrm{pH}$ are greater, and far more rapid, than any change experienced in the past 300 million years. Polar regions will be particularly affected as the Southern Ocean has among the lowest present-day $\mathrm{CaCO}_{3}$ saturation rate of any ocean region, and will therefore be among the first to become undersaturated (Orr et al., 2005).

The ability of marine organisms, populations and ecosystems to adapt to this unprecedented environmental modification is largely unknown and there is particular concern over the ability of highly calcified animals to maintain their skeletons (Kroeker et al., 2010; Ries et al., 2009). So, although there is a sophisticated understanding of calcium regulation in mammals (driven by the interest in ameliorating osteoporosis, for example), data describing calcium pathways in non-model species are seriously lacking and this is especially so in the Antarctic. However, without this fundamental knowledge, we cannot start to obtain the fine-scale detail needed to understand the complex effects of life in an altered pH environment.

To start to redress this balance, studies were initiated on the Antarctic bivalve L. elliptica. A 454 transcriptome from mantle tissue (the organ that secrete the shell) was generated and the transcripts for putative genes involved in the production of the extracellular calcium matrix were determined (Clark et al., 2010). This data is publicly available in the National Center for Biotechnology Information Short Read Archive (accession number SRA011054). The group is now analyzing this data further, in particular, the highly abundant transcripts which are specific to the mantle tissue and presumably involved in shell production, but have no associated functional annotation, i.e. they are "unknown" genes.

\section{Microbial plankton during the Arctic winter - Carlos Pedrós-Alió and Laura Alonso-Sáez}

The most recent research of this group in the polar zones has concentrated in two areas. The first one is the study of the microbial food web during the winter and the second is the analysis of microbial diversity in polar waters. Polar waters during winter are still two of the least known ecosystems in the world. Due to their remoteness and harsh conditions, logistics are complicated and expensive. Therefore, most studies have been carried out during late spring and summer. Yet, an understanding of the winter ecology is essential as it predicts everything that occurs during the spring and summer. Given that the biota of the polar zones is threatened by global warming, particularly in the Arctic, understanding how this winter microbial food web functions is a pressing need to improve the accuracy of models and predictions for the future.

There has been an active participation in two cruises on board the CCGS Amundsen where the ship spent almost a whole year in the Amundsen Gulf. During the CASES cruise (November 2003-August 2004) the ship was frozen in Franklin Bay. In the CFL cruise (December
2007-August 2008), the ship cruised around a polynya in the Amundsen Gulf. This provided the opportunity to study the microbial community throughout the winter (Vincent and Pedrós-Alió, 2008; Vincent et al., 2008). Even though Fridtjof Nansen had already carried out studies of ice microorganisms during the winter in 1893-96, only one cruise had attempted this in modern times (Sherr et al., 2003).

Chlorophyll $a$ decreased during the autumn and early winter reaching a minimum of around $0.03 \mu \mathrm{g} / \mathrm{L}$ in the middle of February. From this point on, chlorophyll $a$ started to increase exponentially. The increase was due to small flagellates, particularly Prasynophites. A Micromonas pusilla flagellate was responsible for most of the assemblage. Studies with a pure culture of this organism showed it to be adapted to low temperatures and light intensities similar to those found under the ice in February. Micromonas was found in abundance in many areas of the Arctic Ocean and it was shown to phylogenetically cluster with other Arctic species (Lovejoy et al., 2007). The winter flagellates were grazed by large nanoflagellates. This short trophic chain was the first to appear after the winter darkness. Interestingly, the grazing rate measured experimentally was of the same order of magnitude as the net decrease of the chlorophyll from November to February (Vaqué et al., 2008). Thus, if there had been no grazing, the algae would have remained at a constant concentration through the dark period. How these animals manage to survive through darkness is still unknown.

The activities of the heterotrophic bacteria were studied with Biolog plates (Sala et al., 2008) and micro-autoradiography combined with FISH (Alonso-Sáez et al., 2008). We found an intense utilization of polymers, particularly polysaccharides, during the winter. This suggests that in the absence of fresh low molecular weight organic matter, the bacteria degrade polymers left over from the previous summer bloom or released by the ice algae. The bacterial assemblage used different simple organic molecules such as glucose, amino acids or ATP and the number of active cells increased from $60 \%$ in the winter to more than $90 \%$ in the spring and summer.

The Archaea results produced a paradox. They were growing exponentially during the winter but we could not see a significant percent of the cells active with any substrate (Alonso-Sáez et al., 2010). In the CFL cruise, we tried to feed them with leucine (as a tracer for heterotrophic activity) and with bicarbonate (for autotrophic activity). The Archaea were not active with either. Gathering pieces of information from dissolved nitrogen, urea uptake experiments, qPCR detection of ammonia oxidation and urea utilization genes plus a metagenomic analysis, we proposed that the Archaea grow using urea which provides both the $\mathrm{CO}_{2}$ and the ammonia necessary for their autotrophic growth (Alonso-Sáez et al., 2012).

The diversity of bacteria was analyzed with 454 pyrosequencing of the 16S rDNA gene. Together with other researchers, we compared samples from the Arctic and from Antarctica. The communities from both polar areas were closer to each other than to those from temperate waters. However, Arctic and Antarctic communities were significantly different from each other. Thus, if global warming changes the Arctic Ocean significantly, extinction of microbial assemblages is a possibility (Ghiglione et al., 2012).

In the future, studies by the team of Pedrós-Alió and Laura Alonso-Sáez are aimed to carry out winter research to test the hypotheses generated during CASES and CFL cruises, as understanding the winter ecology of the polar zones is an urgent need in the context of global warming.

\section{Effects of global warming and ice melting on the microbial food web in polar regions: thresholds of sustainability - Dolors Vaqué, Susana Agustí, Ester Serrão, Gareth Pearson and Carlos M. Duarte}

The current research of this team in polar regions addresses the effects of global warming on marine polar ecosystems, particularly the consequences of ice melting on the functioning of the microbial food web. The consequences of climate change on polar ecosystems 
were investigated taking into account the effect of temperature and the impact (direct or indirect) of melted ice on plankton components (from virus to eukaryotic microorganisms) in Arctic and Antarctic waters. Warming is particularly intense in the Arctic, where temperatures are increasing at rates of $0.4{ }^{\circ} \mathrm{C}$ per decade (ACIA, 2004), this is in contrast to the Antarctic Ocean, where warming is restricted to the Antarctic Peninsula. The consequences of these increasing temperatures are already evident in the Arctic; for example, the loss of ice coverage is now affecting the habitat of large mammals, birds and humans (Duarte et al., 2012; Smetacek and Nicol, 2005). Also, extensive sea ice melting has led to major changes in the biogeochemistry (Chen et al., 2003; Wassmann et al., 2011) of the Arctic Ocean and in the functioning of microbial food webs (Boras et al., 2010). However, most research has focused on the summer period, and there are still few annual or over-winter microplankton data for the Arctic (Forest et al., 2011; Vaqué et al., 2008) or Antarctic (Kang et al., 2002) Oceans to confirm these changes and to build carbon flux models (Danovaro et al., 2011) to help understand the role of microplankton in this changing scenario.

This research has also included a series of projects under the Spanish Antarctic program, funded by the former Spanish Ministries of Science and Science and Innovation, by the 7th Framework Program of the EU and a project funded by the Fundação para a Ciência e a Tecnologia (Portugal), co-funded by FEDER, with the team of Ester Serrão and Gareth Pearson (Centre of Marine Sciences of the University of Algarve). These studies included six oceanographic cruises along the Antarctic Peninsula and the Weddell and Bellinghausen Seas area: ESEPAC-2000 (January-February 2000), TEMPANO (December 2002), ICEPOS-2005 (February 2005), ATOS-Antarctic (January and February 2009), on Board the R/V BIO-Hespérides, and ICEPOS 2004 (between midJanuary and beginning of February 2004) aboard the Spanish RV Las Palmas. ATOS (Atmospheric Transport of Carbon and Pollutants to the Polar Oceans) was a bi-polar IPY 2007-2008 project contributing to OASIS, GEOTRACERS and ICED, and included the oceanographic cruise ATOS-Arctic (July 2007) along the Greenland current and the Arctic Ocean North of the Fram Strait at the ice border and a cruise in the Southern Ocean (ATOS/Antarctic). Additional Arctic activities included several oceanographic cruises in the Norwegian RV Jan Mayen
(2006-2012) as part of the project ATP (Arctic Tipping Points) and a collaborative program within the network ARCTOS coordinated by Paul Wassmann (Tromsø University, Norway). In addition to oceanographic cruises, experimental research has been conducted from land. Two large-scale experiments were conducted in the Spanish Antarctic Base "Juan Carlos I" (Livingston Island, Antarctica) in connection with the ESEPAC and ICEPOS projects. Mesocosm experiments were also conducted in the Arctic at the UNIS (University Center in Svalbard, Longyearbyen, Svalbard Islands, Norway), during July 2009 and June 2010 as part of the ATP project.

The ESEPAC project pioneered the use of large mesocosm experiments in coastal Antarctic waters, particularly to test planktonic responses to changes in solar radiation and nutrients that may be forced by climate change in Antarctica. Large mesocosms (Fig. 3) were deployed in South Bay (Livingston Island, Antarctic Peninsula) in 1999 (a pilot experiment) and in 2000 (8 mesocosms of $14 \mathrm{~m}$ depth and $55 \mathrm{~m}^{3}$ of volume each) involving complex logistics due to the isolation of the area. The project involved over 30 scientists, the key participation of the Spanish Navy (crew of the BIO Hesperides) and the UTM (Unit for Marine Technology, CSIC), and required the use of several Spanish infrastructures in Antarctica (i.e. the R/Vs Las Palmas and BIO Hesperides, and the Spanish Antarctic Base Juan Carlos I). The manipulation of solar radiation and nutrients (i.e. ammonium) in the mesocosm experiments resulted in large phytoplankton blooms up to $100 \mathrm{mg} \mathrm{m}^{-3} \mathrm{Chl} a$ (Agustí and Duarte, 2000; Agustí et al., 2009). The results indicated that phytoplankton blooms in the coastal Antarctic Peninsula may be controlled by solar radiation, and suggested a key role for ice dynamics in determining light and ultraviolet radiation levels in the water column by stratification and mixing. Also glacial and iceberg discharges of suspended solids and nutrients played a significant role (Agustí and Duarte, 2000; Agustí et al., 2009). The mesocosm experiments offered valuable insights into the thresholds for net autotrophic community production (Agustí and Duarte, 2005) and on the responses of the planktonic community (Agawin et al., 2002; Duarte et al., 2005).

The effect of temperature on microbial food webs was experimentally studied during the TEMPANO cruise (Antarctic Ocean), the ATOS-Arctic and ATOS-Antarctic cruises as well as those conducted at Longyearbyen, Svalbard, under the ATP project. The experimental

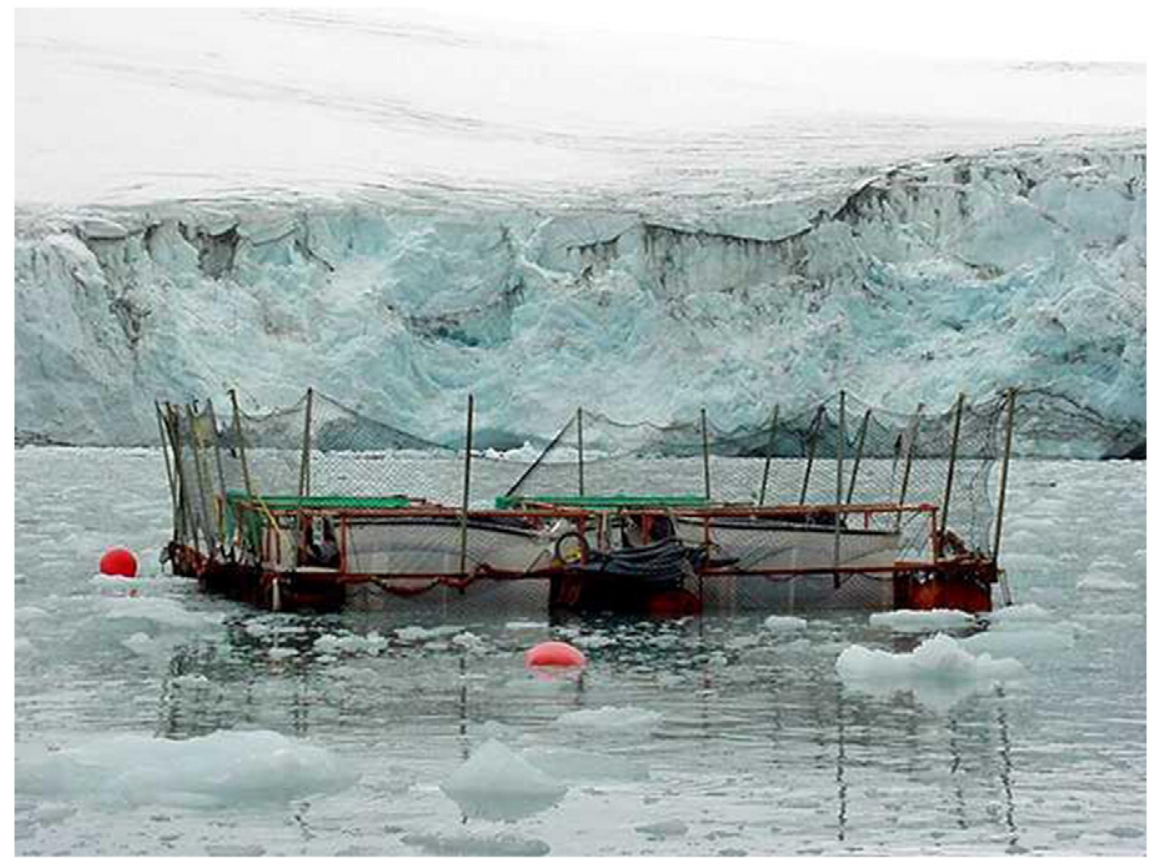

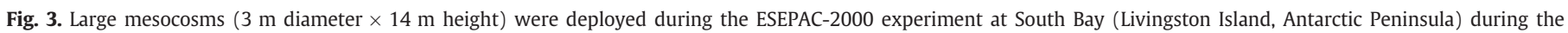
summer of 2000 to study coastal Antarctic plankton responses to environmental changes. 
results showed that bacterial abundance, production and grazing rates (Vaqué et al., 2009) responded greatly to relatively small increases of temperature. However, the responses of grazers (nanoflagellates and ciliates) were more difficult to detect, probably due to cascade effects (Vaqué et al., 2004). In the ATP experiments, we also identified the presence of temperature thresholds triggering shifts from autotrophic to heterotrophic communities and a decline in the cell size of autotrophs, from a predominance of large celled diatoms and dinoflagellates to pico-nanoplankton, such as Micromonas sp. and Pheocystis sp., respectively (Coello et al., pers. comm.). In fact Micromonas sp. is regularly present in the Arctic Atlantic sector, where it develops blooms (Lovejoy et al., 2007). As the phototrophic biomass and cell size declined, the heterotrophic community increased (Lara et al., in press). Accordingly, the warming triggered a shift from autotrophic communities to heterotrophic ones beyond $5{ }^{\circ} \mathrm{C}$, favoring heterotrophic microbial biomass and processes, with a potentially large impact on carbon and nutrient cycling and carbon storage in the Arctic Ocean. We show the average values of biomasses and bacterial carbon fluxes, grouped into two temperature intervals equivalents to cold $\left(1-4{ }^{\circ} \mathrm{C}\right)$, and warm $\left(5.5-10^{\circ} \mathrm{C}\right.$ ) conditions (Fig. 4). However, a more variable response of Antarctic phytoplankton to experimental increases in temperature was found, with some species of diatoms increasing in growth rates with increasing temperature, probably due to the higher nutrient availability in Antarctic waters than in the Arctic waters (Coello and Agustí, unpublished data).

The ATOS-Arctic cruise was conducted in the summer of 2007 when record ice-melting occurred, offering the opportunity of directly studying the consequences of massive ice melting for the Arctic planktonic community (Agustí et al., 2010). Planktonic communities were greatly impacted by ice melt, and primary production and net community production were suppressed in the low salinity surface waters receiving the melted ice (Alcaraz et al., 2010; Lasternas and Agusti, 2010; Regaudie-de-Gioux and Duarte, 2011). Significantly more carbon was channeled to protists in waters affected by ice melting than in unaffected waters. However, release of DOM due to viral lysis was also suppressed in receiving ice melt waters (Boras et al., 2010). These results indicated that sea ice melting in the Arctic could impact the carbon flow through the microbial food web. This process may be especially important in the case of massive sea ice melting due to climate change (Boras et al., 2010). Furthermore, when the substrate preferences of bacteria for growth were analyzed using Biolog ecoplates (Sala et al., 2010), it was observed that the ice melting might induce changes in the bacterioplankton functional diversity by enhancing the turnover of carbohydrates. This could have ecological and biogeochemical implications for the future of the Arctic Ocean. Since organic aggregates are mainly composed of polyssacharides, higher solubilization of aggregates might modify the carbon cycle, weakening the biological pump.

During the ATOS-Arctic cruise we observed that the atmospheric concentrations of pollutants declined pole-ward during atmospheric transport over the Greenland Current with estimated half-lives of 1-4 days (Galbán-Malagón et al., 2012). These short half-lives can be explained by the high air-to-water net diffusive flux, which is similar in magnitude to the estimated settling fluxes in the water column. Therefore, the decrease in atmospheric concentrations is due to sequestration of atmospheric polychlorinated biphenyls by enhanced air-water diffusive fluxes driven by phytoplankton uptake and organic carbon settling fluxes (biological pump). Experimental assessments of the sensitivity of polar phytoplankton to pollution carried out in the ATOS cruise revealed that Arctic phytoplankton was more resistant to PAHs (polycyclic aromatic hydrocarbons) than Antarctic phytoplankton (Echeveste et al., 2011).

The effect of the compounds accumulated in sea ice was estimated experimentally over several years by atmospheric deposition (e.g. organic matter, pollutants) on the microplankton community (Tovar-Sánchez et al., 2010). To this end, "multiyear" ice cores were collected in the Arctic and from glaciers or icebergs in the Antarctic. Melted water from slices of ice from the top and bottom of cores were added to water samples. Ice additions from the top of cores produced a decrease in chlorophyll $a$ and primary production, and an increase in bacterial abundance and production and exoenzymatic activities (Arrieta et al., unpublished data). Less effect was produced with the addition of ice from the bottom of the ice cores. This would suggest, again, that ice melting associated with global warming will benefit and shift towards a dominance of heterotrophic processes in the Arctic ecosystem.

All these observational and experimental studies point to the same conclusion; a shift in the balance between heterotrophs and autotrophs in the ecosystem towards a prevalence of heterotrophic organisms and metabolism with warming and ice melt. However, these findings require confirmation, particularly by extending our research during cold seasons and in different sectors of the Arctic and Antarctic Oceans other than those studied until now.

The ATOS-Antarctic cruise also provided the opportunity for Iberian collaborations on metatranscriptomics research funded by the Fundação para a Ciência e a Tecnologia (Portugal) on diatom-dominated eukaryotic communities. This project resulted in next generation sequencing datasets for distinct Antarctic diatom-dominated communities from the Weddell Sea, the Bransfield Strait and from sea ice from the Wilkins Ice Shelf (the samples from the latter location had just collapsed). The diatom transcripts revealed that sea ice diatoms overexpressed photoprotective genes (light stress) and under-expressed genes for energy

\section{$\operatorname{COLD}\left(1^{\circ}-4^{\circ} \mathrm{C}\right)$}

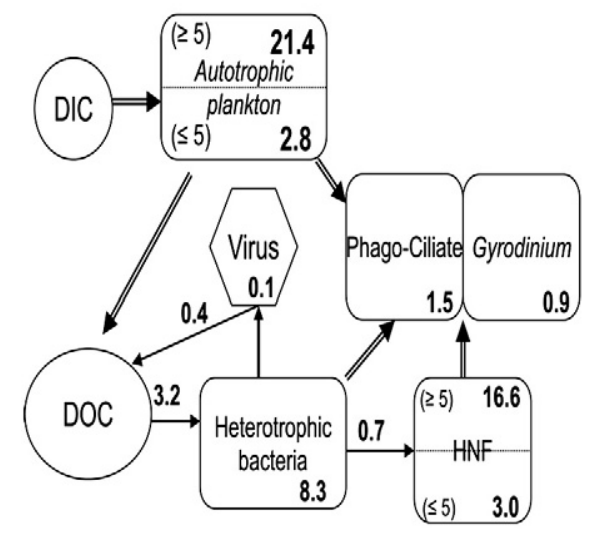

WARM $\left(5.5^{\circ}-10^{\circ} \mathrm{C}\right)$

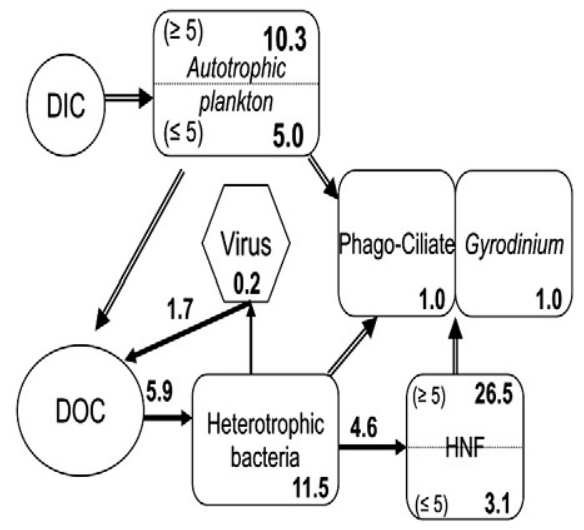

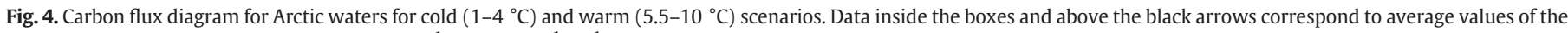

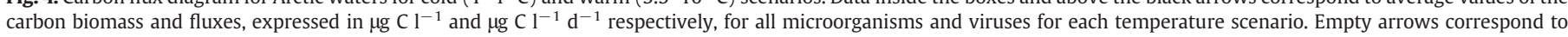
fluxes that were not estimated. 
metabolism. The Weddell Sea and Wilkins communities over-expressed genes responsive to cold conditions such as for adjustment of membrane fluidity, cold-shock transcription and ice-binding proteins. Iron limitation in the Bransfield Strait diatoms was suggested by their expression of genes involved in Fe-transport. Ammonium transporters for N-metabolism were overexpressed in the Bransfield Strait communities. The sea-ice diatoms from Wilkins appeared well supplied with oxidized $\mathrm{N}$ sources. $\mathrm{N}$-limitation in the post-bloom Weddell communities was suggested by their under-expression of a key $\mathrm{N}$-assimilation enzyme. Experimental gene expression by the communities was also assessed by metatranscriptomics in response to UV variations and reduced $\mathrm{N}$ from Antarctic krill excretion products. Additionally, Antarctic krill were also used in experiments that revealed the genes expressed in response to UV and starvation, and neutral genetic markers (microsatellites) were developed for this species for use in future studies.

The effect of temperature on phytoplankton metabolism is also being investigated using multiple approaches including metatranscriptomics of Arctic phytoplankton communities studied in the ATP project. The key copepod species in the Arctic, Calanus glacialis, is also being investigated for its genetic responses to temperature change using transcriptomics, and for population genetic structure, using our newly developed microsatellites.

\section{Distribution of meroplankton in West Antarctica - Elsa Vázquez and Julia Ameneiro}

Antarctic marine invertebrates have developed adaptations such as low metabolic rate, slow growth rate, longevity and gigantism in response to the intense cold and to strong seasonality in the environment. In terms of reproduction, strong seasonality with delayed maturity, low fecundity, large eggs and nonpelagic larval development were also considered as adaptations to Antarctic conditions (Arntz and Gili, 2001; Poulin et al., 2002). However, recent studies in the Southern Ocean have revealed a relatively high diversity and abundance of larval forms (Absher et al., 2003; Ameneiro et al., 2012; Arntz and Gili, 2001; Bowden et al., 2009; Freire et al., 2006; Sewell, 2005; Shreeve and Peck, 1995; Stanwell-Smith et al., 1999). Some of these larvae are planktotrophic and synchronize the presence of their larvae with that of summer phytoplankton (Bowden et al., 2009; Pearse and Bosch, 2002; Pearse and Lockhart, 2004; Pearse et al., 1991; Stanwell-Smith et al., 1999).

Despite the general acceptance that, at least for some phyla, an important proportion of Antarctic marine invertebrates have pelagic development, few studies had attempted to explain the distribution of meroplankton in the Southern Ocean. Exceptions were a two-year study by Stanwell-Smith et al. (1999) at Signy Island, where 131 morphologically distinct larval forms were collected throughout the year, and a study of the distribution of pelagic larvae of benthic marine invertebrates in the Bellingshausen Sea, by Shreeve and Peck (1995), in which sixteen larval and juvenile types, representing seven phyla, were reported. Finally, the studies by Freire et al. (2006) reported seasonal variation in invertebrate larvae in Admiralty Bay in King George Island. Since 2003, we have been conducting studies on the spatial distribution of meroplankton and their relationships with hydrographical conditions in the Bransfield Strait (BREDDIES 2003 and COUPLING 2010 cruises), Drake Strait (COUPLING 2010 cruise) and Bellingshausen Sea (BENTART 2006 cruise) in Antarctica (Fig. 5), all of them on board R/V Hespérides. Zooplankton samples were taken using different plankton nets (BIONESS, MOCNESS, and an $80 \mu \mathrm{m}$ mesh plankton net with a 0.28 $\mathrm{m}$-diameter opening) from surface waters through to $300 \mathrm{~m}$ depth. To characterize the water masses, phytoplankton and bacterial compositions, a Neil Brown Mark III CTD/Rossette Niskin was used.

A strong meroplanktonic larval dependence on water masses, depth, and fronts was identified in the Bransfield Strait (Vázquez et al., 2007). The meroplankton community was very diverse and included 16 types of larvae, dominated by polychaete and echinoderm larvae. The meroplankton were sparse in the Antarctic Peninsula and remarkably increase in number towards the South Shetland Islands in the Bransfield Current probably due to hydrographical structures that could retain the larvae (Sangrá et al., 2011) and to the large biomass of sedentary polychaetes and echinoderms in the region (Arnaud et al., 1998; Ramos, 1999). Polychaete larvae were found close to both shores but mainly close to the South Shetland Islands in the transitional Bellingshausen water; they were very sparse in the central basin, although they were abundant below $100 \mathrm{~m}$ depth in the transitional Weddell water, and increased in abundance in upper layers at stations between the hydrographic front and the Antarctic Peninsula, in transitional Weddell water. By contrast, echinoderm larvae mainly occupied the central basin and were always associated with the upper $100 \mathrm{~m}$ in transitional Bellingshausen water, just above the polychaete larvae, probably due to high nanophytoplankton abundance in this water mass (Vazquez et al., unpublished data) and were almost absent from transitional Weddell water.

The abundance of ascidian larvae in the Antarctic Sound station was remarkable, but this was probably due to the proximity to coastal adult populations (Sahade et al., 1998; Sáiz-Salinas et al., 1997). In the Drake Passage, diversity and larval abundance were lower than in the Bransfield Strait. Nineteen larval types were found including echinoderm larvae, mainly brachiolaria of Asteroidea, polychaete larvae, and veligers of nudibranch (Vazquez, unpublished data).

In the Bellingshausen Sea, fifteen types of larval benthic invertebrates were found, with gastropod echinospira veligers and nudibranchs the most abundant, although a high degree of spatial variability in both larval abundance and larval types across the Bellingshausen Sea was noticed (Ameneiro et al., 2012). The variability was significantly correlated with total chlorophyll- $a$ concentration and the contribution of large $(>5 \mu \mathrm{m})$ phytoplankton to total chlorophyll, indicating the availability of food as an important factor in the larval distributions. Nudibranch veligers, nemertean pilidia, echinoderm and planula larvae were more abundant at stations in the central Bellingshausen Sea, which was characterized by low phytoplankton biomass and production. Higher abundances of gastropod veligers and polychaete larvae were found at the more productive stations close to Peter I Island and the Antarctic Peninsula. In summary, meroplankton distribution in West Antarctica appears to be the product of adult spawning and hydrography. Spawning by adults establishes the initial distribution of eggs and larvae, but the local hydrographic conditions may determine larval dispersal. The abundance and diversity of larval types found support the hypothesis that indirect development through larval swimming stages plays a key role in benthic recruitment in polar areas.

\section{Pelagic-benthic coupling over the Antarctic continental shelf - Enrique Isla, Elisabet Sañé, Josep-Maria Gili, Sergi Rossi, Albert Palanques}

For more than ten years, this group has focused mainly on the analysis of the benthic-pelagic coupling (i.e. interactions and cycling of nutrients between the bottom sediments and overlying water column) over the continental shelf. They have participated in several expeditions to both coasts of the Antarctic Peninsula and the high-latitude Weddell Sea. They have collected ice, water, benthos and sediment samples and have also moored instruments such as sediment traps and current meters for different periods of the year, which, in some cases have produced annual datasets.

The main research areas include the study of the biochemical characteristics of sea ice, suspended particles and seabed sediment as well as the tissue and stomach contents of selected benthic species. Regarding the benthos, this group also studies ecological processes such as community dynamics and resilience after disturbance (e.g. iceberg scouring) and taxonomy. 
Total meroplankton larvae
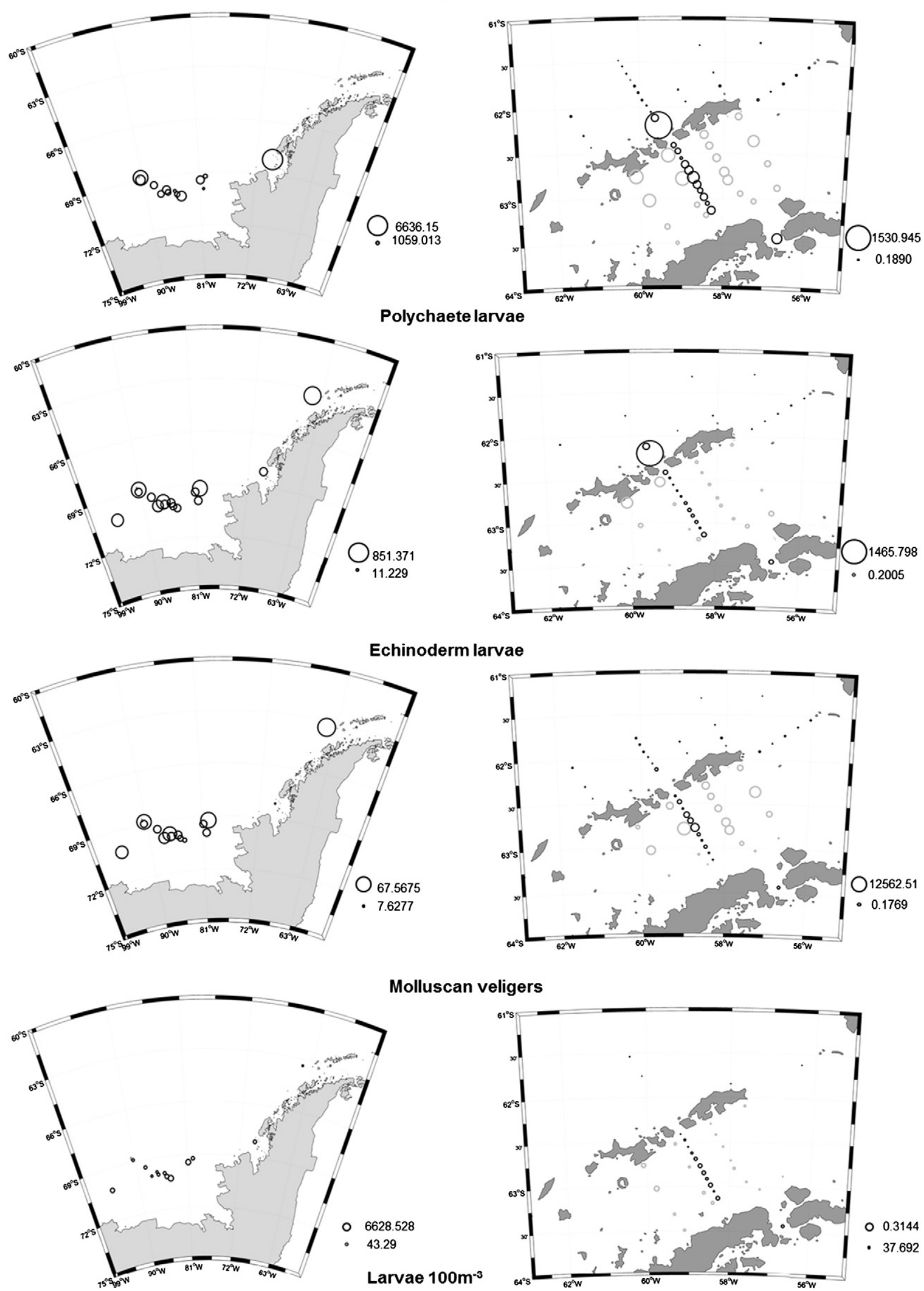

Fig. 5. Abundance (larvae $100 \mathrm{~m}-3$ ) of total meroplankton and the main larval groups in the upper $200 \mathrm{~m}$ sampled during the BENTART cruise (left column) and the BREDDIES and COUPLING cruise (right column). The gray circles represent the COUPLING sampling stations. 
Their findings can be carried out by describing some features of the benthic-pelagic coupling over the continental shelf from top to bottom starting with the formation of sea ice during autumn and early winter, when microalgae become trapped in brine-filled, micro-channels within the ice giving it a brownish color. This part of the sea ice has up to one order of magnitude higher concentration of lipids than the surrounding sea water (Rossi et al., unpublished data). When the spring comes, this high load of organic material is released and together with the high nutrient concentration of Antarctic waters, sets conditions for phytoplankton to bloom. As a consequence, the most intense annual pulse of organic matter to the sea floor develops, delivering a flux of biogenic silica and organic carbon (Isla et al., 2009; Palanques et al., 2002) that accumulates on the seabed as nutritious green mats also known as food banks. This flux of fresh organic matter only takes days to reach the seabed and is accelerated and stimulated due to the action of wind storms (Isla et al., 2009). The green mats act as food reservoirs which are reincorporated to the water column due to the constant action of the tides (Isla et al., 2006a), which enable benthic communities to have food available throughout the year, especially during the dark months when primary production is negligible (Orejas et al., 2003). As a result, in the autumn, when the productive season has finished, the biochemical characteristics of seabed sediment present good nutritive conditions due to its high lipid contents in contrast to the low concentrations found at the early spring just before the annual bloom is going to take place (Isla et al., 2006b; Isla et al., 2009) and the sediment lipid contents have been exhausted by benthic consumption (Isla et al., 2011). Another mechanism of efficient organic matter transfer to the benthos is through the migration and consumption of the salps Salpa spp., which directly feed on phytoplankton at the upper layers of the water column and when migrating close to the seabed, they are captured by the benthos (Gili et al., 2006a). This equilibrium between atmospheric conditions and the biological and physical characteristics of the water column has been taking place for millennia, enabling the development of diverse and highbiomass benthic communities (Gili et al., 2001; Gili et al., 2006a,b) with comparable values to those found in lower-latitude coral reefs. These Antarctic benthic communities mainly comprise suspension feeders which support a complex epifaunal assemblage (Teixidó et al., 2002; Teixidó et al., 2004). These communities are regularly disturbed by iceberg scouring, which frequently erodes the sea floor creating space for re-colonization and stimulating benthic community dynamics (Teixidó et al., 2004; Teixidó et al., 2007).

Due to the anthropogenic global warming along the Antarctic Peninsula, large sections of ice sheets have been collapsing during the last three decades presenting opportunities for studying how the benthic ecosystem responds to drastic changes at the sea surface. Off the eastern coast, the sections A and B of the Larsen ice shelf collapsed a decade ago enabling primary production and a consequent flux of organic matter to the seabed. On the one hand, organic matter concentrations in the upper centimeters of the sediment column in the regions where the former sections A and B of the Larsen ice shelf existed presented similar values to those found in areas without ice shelf influence such as off the Elephant and the South Shetland Islands (Sañé et al., 2011). On the other hand, currents measured close to the sea floor showed similar velocities and a tidal pattern as those observed off Austasen at the south-eastern Weddell Sea shelf (Isla et al., unpublished results), suggesting that there is enough energy to redistribute the settled organic matter, making it available for benthic suspension feeders. These conditions support a dynamic benthic re-colonization comparable to that observed at the south-eastern extreme of the Weddell Sea after iceberg scouring events (Sañé et al., 2012a). The incorporation of organic material into the sediment column is supporting early benthic re-colonization on the continental shelf, which is transforming the ecology of the benthic realm (Gutt et al., 2011). It was also found that currents provided a limited amount of organic matter via lateral transport that helps maintain a poor benthic community before the ice sheet collapses (Sañé et al., 2012b). The study of these areas may provide clues on how the communities at the south-eastern extreme of the Weddell Sea evolved across glacial periods.

Given the accelerating pace of anthropogenic climate change and the lack of knowledge on the functioning of Antarctic ecosystems, studies on benthic-pelagic coupling are urgently required to enable us to predict how the Antarctic shelf ecosystems will cope with ongoing environmental changes and their potential fate.

\section{Biodiversity of high Antarctic marine benthic biota - Josep-Maria Gili, Pablo J. López-González, Núria Teixidó and Codavonga Orejas}

Antarctic benthic communities have a predominantly circumpolar distribution as a result of oceanographic conditions produced by the circumpolar currents. However, there is also significant spatial heterogeneity generated by variations in ice cover, sediment dynamics, and local hydrodynamic and trophic factors. Current data suggest that the continental shelves of the Weddell and Ross seas exhibit the greatest diversity and the highest biomass levels in Antarctica. Indeed these habitats, extending from the edge of the continental ice sheet beyond the shelf edge, often to depths greater than $600 \mathrm{~m}$, are among the richest in terms of sessile fauna in the world ocean (Clarke et al., 2004). These benthic communities display a key characteristic that differentiates them from most other shelf ecosystems: sessile suspension feeders living mostly on soft substrata dominate them. Assemblages of sponges, bryozoans, Anthozoans, and ascidians on these bottoms produce benthic communities with complex three-dimensional structures, similar to those found on rocky bottoms in temperate or tropical seas, such as coral reefs or the hard-bottom communities of the Mediterranean (Gili and Coma, 1998). Soft bottoms predominate on the continental shelves of the world's oceans, and sessile suspension feeders are commonly found there. But the species richness and structural development of such communities are much less pronounced than in the Antarctic, and deposit-feeding, or burrowing, organisms tend to dominate instead (Gili et al., 2006a). Factors such as input of fine sediments or the presence of bioturbating organisms can result in the clogging of filtering organs and/or instability of the substratum and thereby interfere with the development of sessile suspension-feeding assemblages on continental shelves (Gili et al., 2001; Orejas et al., 2000). The presence of dense populations of sessile suspension feeders tends to increase the stability of the substratum through retention and consolidation of the sediment, thereby creating a favorable habitat for settlement of many species. Antarctic epibenthic communities thus comprise a three-dimensional assemblage providing a broad range of habitats that can be colonized by a large number of species, a property that may explain the high species richness found in these ecosystems (Gili et al., 2001). In recent years, detailed studies carried out in the Weddell Sea and other regions of the high Antarctic continental shelf have demonstrated the richness and high degree of heterogeneity of communities dominated by sessile suspension feeders, many of which extend continuously over hundreds of meters or kilometers (Arntz et al., 2005; Teixidó et al., 2002). The present composition of these communities has been attributed both to ecological and historical factors (Gili et al., 2006a). While the overall importance of historical factors such as variation in the extension of the ice shelf is well recognized within the Tertiary, it is now clear that some elements of the present Antarctic fauna can be traced back to the Mesozoic (Clarke et al., 2004; Gili et al., 2006a).

The general hypothesis put forward by Josep-Maria Gili and his group is based on the possibility that survivor species of the last great biological extinction at the end of the Cretaceous (K/T event; also known as the Cretaceous-Tertiary extinction event), using the deep sea as a refuge, recolonized the high Antarctic shelf when the environmental conditions changed in a way that facilitated this colonization process. An alternative hypothesis is that the similarity in structures and lifestyles of present-day Antarctic communities with 
those at the end of the Cretaceous is a convergent development, which is due to a similar environmental setting and hence the high Antarctic benthic assemblages are probably the oldest marine benthos shelf communities in the world (Gili et al., unpublished data). The research results of Josep-Maria Gili and his group suggest that the three-dimensional, epi-benthic communities of passive suspension feeders, which dominate high Antarctic seafloors in the Weddell and Ross Seas, are partly derived from Cretaceous ancestors. Contrary to the situation in other continents, the Antarctic forms presumably survived the K/T event because their environment developed similarities with that of the late Cretaceous, and above all, restricted sedimentation due to reduced terrestrial runoff and favorable feeding conditions. Evidence for this hypothesis is provided from some consequences of the late Cretaceous catastrophy $\mathrm{K} / \mathrm{T}$ event concerning changes in oceanic circulation, plankton communities, particle input and sedimentation, and from specific Antarctic features such as the ice shield, restricted sedimentation, isolation, retarded life strategies and the lack of herbivores and large predators. Both direct survival of ancestral species and development of convergent life forms under similar conditions may have contributed to the apparent "Mesozoic aspect" of the high-Antarctic suspension feeder communities, thus complementing the origin of other faunal elements via immigration across the deep sea and pelagic drift between shallow sites.

Our systematic studies that support the general hypothesis (see above) have been addressed mainly using Cnidarian groups. The level of endemism of many groups of sessile benthic organisms has been shown to be very high, indicating a long period of evolutionary isolation on the Antarctic shelf. Though fragmentary, the fossil record for certain groups of benthic marine invertebrates can shed some light on the origin and diversification of the Antarctic fauna. Gorgonian octocorals are a case in point, with high Antarctic benthic assemblages being dominated by two families, Primnoidae and Isidiidae (López-González and Gili, 2000, 2001, 2005; Zapata-Guardiola and López-González, 2012). Other families such as Chrysogorgiidae, Acanthogorgiidae, and Subergorgiidae are found only at lower latitudes in the Southern Ocean, mainly in the Scotia Arc. Fossil remains identifiable as Primnoids and Isidiids have been found in Cretaceous deposits, whereas the other families are considered to have evolved more recently (Gili et al., 2006a). A Cretaceous fauna dominated by gorgonians could represent the origin of the present Antarctic fauna, with subsequent isolation resulting in a level of endemism reaching $50 \%$ at the genus level among Primnoids (Arntz and Gili, 2001; LópezGonzález et al., 2002). The presence of other gorgonian families in the southern segment of the Scotia Arc probably represents more recent re-colonization from the surrounding oceans. The pattern observed for gorgonians is typical of the trends observed for other groups such as sponges (Uriz et al., 2011). Thus, a Cretaceous origin for the present-day fauna is also suggested, for example, for the hexactinellid (glass) sponges, one of the most significant groups of Antarctic benthic fauna in terms of biomass and abundance (Teixidó et al., 2006). Other studies in the same research area corroborate not only the high level of endemism but also the importance of carrying out joint systematic and ecological work such as that carried out over the last decade by our group (Gili et al., 2006b; Orejas et al., 2002; Rodríguez et al., 2007).

\section{Biodiversity, ecology, biogeography and evolution of the Antarctic benthic hydroids - Álvaro L. Peña Cantero}

The Antarctic research of the Cnidarian Biodiversity and Evolution group is focused on the biodiversity, ecology, biogeography and evolution of the Antarctic benthic hydroids.

Since the group started on the study of Antarctic hydroids (with the collection gathered during the Antártida 8611 Spanish Antarctic expedition), they have shown that the biodiversity of this zoological group in the Southern Ocean is much higher than originally thought. They have also demonstrated its wide representation and importance in the Antarctic epibenthic communities, and developed its potential role for understanding the evolution of the Antarctic marine biota.

In spite of the existence of large Antarctic areas in which the hydroid fauna is still little known or completely unknown, it is clear that hydrozoans constitute one of the most diversified and characteristic zoological groups in the Antarctic benthic ecosystem, with wide representation in different epibenthic communities. In addition, there are some crucial peculiarities specific to this taxa that complicate the understanding of its origin and evolution. These include the relatively low diversity at the generic level, the high level of endemism at the specific level (ca 80\%), restricted to a few genera, and a specific diversity also restricted to a few, presumably monophyletic groups (Peña Cantero and García Carrascosa, 1999). The degree of endemism in the Antarctic benthic hydroid fauna is distinctly high among the different Antarctic zoological groups, much higher than the general species endemism rates of around $50 \%$ suggested by Griffiths et al. (2009).

The objectives of the research group are: 1) to increase the scientific knowledge of the biodiversity, ecology and distribution of hydrozoans in the Antarctic benthic ecosystem, 2) to advance the knowledge of the evolution of the most characteristic groups of Antarctic benthic hydroids, 3) to determine the biogeographic models for this zoological group in the Southern Ocean and to try to understand both the ecological and historical causes underpinning those models, and 4) to advance the understanding of the origin of the Antarctic hydroids fauna and, thus, of the Antarctic biota in general.

To carry out the first goal, which is of prime importance to achieve the remaining objectives, the research group has been working on material collected during many Antarctic expeditions organized by different countries, in particular, collections from Australia, Brazil, France, Germany, New Zealand, Russia, Spain and USA. It is worth highlighting the German, Spanish and US collections. The first ones came from the intensive sampling effort carried out with the RV Polarstern in the area of the Weddell Sea, which has made this area one of the best known areas concerning benthic hydrozoans. The US collections, gathered through the United States Antarctic Research Program (USARP), are remarkable for having been obtained from several areas around Antarctica. Finally, the Spanish collections are the result of the Bentart group, which provided funding initiatives to carry out several Antarctic expeditions to study benthic communities in several little-known areas, such as the Bellingshausen Sea, with the participation of specialists in literally every zoological group.

The results have contributed enormously to a better understanding of the biodiversity in this unique ecosystem, of note are the descriptions of two new families, two new genera and 58 new species to science (Table 1). The importance of the last number is even greater when considering the total known hydrozoan diversity in the Southern Ocean, since those new species represent roughly onethird of the total Antarctic hydrozoan biodiversity (and approximately $40 \%$ of the inventory of Leptothecate species). Most of those

Table 1

Number of new species to science of Antarctic benthic hydroids, described by the Cnidarian Biodiversity and Evolution group, distributed by genera and percentage in relation to the total number of known species of those genera in the Antarctic Region and in the world oceans.

\begin{tabular}{llll}
\hline Genera & New species & \% (Antarctic region) & \% (world oceans) \\
\hline Oswaldella & 20 & 77 & 74 \\
Staurotheca & 12 & 52 & 50 \\
Schizotricha & 8 & 57 & 47 \\
Symplectoscyphus & 8 & 42 & - \\
Antarctoscyphus & 4 & 40 & 40 \\
Clathrozoella & 2 & 67 & 50 \\
Other & 4 & - & -
\end{tabular}


species belong just to five genera (Antarctoscyphus, Oswaldella, Schizotricha, Staurotheca and Symplectoscyphus) which embrace over $70 \%$ of the known species. These studies have also shown that Antarctoscyphus, Oswaldella and Staurotheca are mainly Antarctic genera, with just a few species also present in sub-Antarctic waters.

With regard to evolutionary studies, we are testing the monophyly of the most characteristic and dominant groups of Antarctic benthic hydroids. Thus, we carried out the first and, to date, only existing phylogenetic study on Antarctic hydroids, in particular on the genus Oswaldella, demonstrating its monophyly and the validity of its species (Peña Cantero and Marques, 1999). This study was initially carried out using only morphological characters, but subsequently molecular analyses have been developed. We carried out the first molecular-based phylogenetic study on those characteristic, endemic groups that dominate the Antarctic hydroid fauna (Peña Cantero et al., 2010). This study also confirmed their monophyly and identified a new family of hydrozoans. The evolutionary studies continue with the aim of establishing the phylogenetic relationships within those dominant Antarctic groups. We are working, at present, with several nuclear and mitochondrial markers to understand the evolution of the genera Antarctoscyphus, Oswaldella, Staurotheca, Schizotricha, and Symplectoscyphus.

In terms of biogeographical studies, we are trying to identify the ecological and historical causes underpinning the current biogeographical patterns of Antarctic benthic hydroids. Studies on historical biogeography are practically absent for most marine organisms and completely non-existent for the Antarctic hydrozoans. In addition, in terms of ecosystems, little is known of the Southern Ocean in relation to the establishment of areas of endemism. We are using those characteristic, monophyletic groups in the determination of areas of endemism in the Southern Ocean, through the Parsimony Analysis of Endemicity (PAE). Indeed, we have already carried out first analyses with the species of Oswaldella (Marques and Peña Cantero, 2010).

Our studies have demonstrated that benthic hydrozoans seem to follow the classical hypothesis (i.e. suggesting the subdivisions within the Antarctic Region, originally proposed by Hedgpeth (1969)). They also support the distinction between East and West Antarctica and the subdivision of High Antarctica into two regions based on the delimitation of areas of endemism in the Southern Ocean (Marques and Peña Cantero, 2010).

Our final goal is to advance in the understanding of the origin of the Antarctic hydroid fauna and, thus, of the Antarctic biota in general. This is a very ambitious objective that can only be achieved after having clearly determined the areas of endemism in the Southern Ocean and after obtaining very robust phylogenies of the main groups of Antarctic hydrozoans.

\section{The ACTIQUIM project: chemical and biological diversity in the Southern Ocean - Conxita Ávila, Francisco J. Cristobo, Laura Nuñez-Pons, Sergi Taboada, and Blanca Figuerola}

Traditionally, Antarctic ecosystems were described as old and stable, and therefore interactions between organisms are considered to play a vital role in community structure (Dayton et al., 1974; Paul et al., 2007). The study of interactions between organisms and the environment, and between organisms at intra- and inter-specific level mediated by natural substances provides information on the ecology and biology of the species involved, the functioning and the structure of the community and, simultaneously, new pharmacological products that can be useful for humans (Albericio et al., 2009; Avila, 2006; Avila et al., 2008; Taboada et al., 2010).

Marine chemical ecology has a lag of several decades with respect to terrestrial ecology. However, in the past 20 years much has been achieved thanks to new technologies to capture and study marine samples and the progress in identifying new molecules with ever smaller amounts of products (Blunt et al., 2012; Paul et al., 2011). Marine organisms are currently providing considerable numbers of bioactive natural products, a percentage much higher than those obtained from terrestrial organisms (Albericio et al., 2009; König et al., 2006; Newman and Cragg, 2007). The organisms from temperate and tropical seas were the most studied to date, while the organisms from polar seas were studied in much smaller proportions (Avila et al., 2008; Blunt et al., 2012; Lebar et al., 2007). Recent studies by our group, however, show that the Antarctic benthic invertebrates are a source of natural products rich and varied, highly interesting from the chemical ecology and pharmacological points of view. In addition, some species have been studied from the Antarctic areas of McMurdo Sound and the Antarctic Peninsula that inhabit shallow waters which have chemical defenses (Avila et al., 2008; McClintock et al., 2010). In only a few of such cases have the chemicals involved been fully described and/or its ecological role has been established in the ecosystem.

The ACTIQUIM-II project ("Ecological activity of marine natural products from Antarctic benthic organisms: in situ chemical ecology experiments, pharmacological potential of selected compounds and possible alterations caused by human activity"; CTM 2010-17415/ANT) is the continuation of the previous ACTIQUIM project (CGL2007-65453/ANT). The aims of these projects led by the team of Conxita Ávila are, on one hand, to determine the ecological activity of marine natural products obtained from benthic Antarctic organisms by in situ chemical ecology experiments, and on the other hand, to establish the pharmacological potential of selected compounds described recently by our group. In the ACTIQUIM-II project, we included defense tests against different kinds of predators (including micro-predators), toxicity towards small-sized animals, cytotoxicity, and antifouling activity.

To start with, we carried out a review of all described Antarctic marine natural products derived from animals and algae up to May 2007 (Avila et al., 2008), with special emphasis on the role that these natural products play in their ecosystems. We later reported the results from in situ feeding repellent experiments using lipophilic extracts from benthic invertebrates from two poorly known areas (eastern Weddell Sea and Bouvet Island) (Taboada et al., 2012b). These experiments, carried out using a sympatric predator (Odontaster validus), showed that more than half of the invertebrates tested possess chemical defenses against possible predators. In some cases, these defenses seem to be located in the most exposed/vulnerable parts of the organisms. Similarly, we performed experiments using the omnivorous lyssianasid amphipod Cheirimedon femoratus (Núñez-Pons et al., 2012c). This amphipod proved to be an excellent model for the evaluation of unpalatable chemical defenses against predators in Antarctic communities. Furthermore, the newly designed protocol provided many methodological improvements in feeding preference experiments with simultaneous food choice in Antarctic conditions, with an additional high discriminatory potential for detection of unpalatable activities. Then, we decided to make a comparative study of un-palatability in Antarctic benthic organisms towards these two relevant sympatric consumers and check experimentally whether taste matters in these kinds of experiments (Núñez-Pons and Avila, unpublished data). We observed that deterrent activities were more frequent towards $C$. femoratus than against $O$. validus, principally in nutrition-poor samples, and in macroalgae and sponges.

Regarding biodiversity, we recently described some new species of annelid polychaetes from Antarctic waters (Taboada, 2012; Taboada et al., 2012a,b). These organisms belong to the families Cirratulidae, Dorvilleidae and Siboglinidae (a new species from the genus Osedax), and were described from whale bones experimentally deployed in Deception Island. These findings confirm the importance that whale bones may have in the Antarctic shallow-water ecosystem. Bryozoans also provided new species, and among these species, the first one described by Conxita Ávila's group is a Reteporella (Bryozoa Phidoloporidae) from the Weddell Sea, and we discussed the possible functional morphology of their avicularia (Figuerola et al., 2012a). This new cheilostome bryozoan is characterized by the presence of giant vicarious spherical avicularia. The variability in avicularian morphometrics demonstrates that intraspecific variation between localities may exist. Furthermore, 
we studied the spatial patterns and diversity of bryozoan communities from the Southern Ocean: South Shetland Islands, Bouvet Island and Eastern Weddell Sea (Figuerola et al., 2012b). In this study, we reported new data on the biodiversity and the geographic and bathymetric distribution of bryozoans. A similar study is now being completed for Echinodermata and will be published soon.

In hexactinellid sponges, we carried out a chemo-ecological study which yielded remarkably high unpalatable activities towards the amphipod, while no apparent allocation of lipophilic defenses was noted (Núñez-Pons et al., 2012a). A combination of low nutritional value and weak chemical defenses probably derived from primary metabolites, along with an enhanced regenerative potential, seems to operate in glass sponges and deterred sea star predation in Antarctic waters.

Studies on Alcyonium soft corals also produced very interesting results, since they make extensive use of lipophilic chemical defenses to fight against predation and, to some extent, against bacterial fouling (Carbone et al., 2009). Several illudalanes were present in Alcyonium grandis, two of them being firstly described from Alcyonium roseum. Also, two wax esters were found to be common to all the samples. The illudalane terpenoids, as secondary metabolites, along with the waxes, representing the main energy reserves in corals (primary metabolites), seem to synergistically cooperate in predation avoidance.

Molluscs have provided very useful information about intrapopulation variability in their terpene metabolism (Cutignano et al., 2011). In Holoturians (Echinodermata), we described new triterpene glycosides (Antonov et al., 2008; Antonov et al., 2009; Antonov et al., 2011). Just to mention a few, five new compounds, liouvillosides A1, A2, A3, B1, and B2, were isolated from the sea cucumber Staurocucumis liouviellei. Tunicates of the genus Aplidium from the Weddell Sea were also analyzed for their chemical defenses (Carbone et al., 2012; Núñez-Pons et al., 2012b). All ascidian samples tested possessed defenses towards $O$. validus. The meridianins A-G were demonstrated to be responsible for such strong feeding deterrent activities. They were abundant in the inner as well as in external body-regions of the specimens analyzed, even if they were more concentrated in the trunk of the animal. These indole alkaloids have been reported in our studies for the first time in Aplidium falklandicum. It is noteworthy that meridianin D was exclusively present in Aplidium meridianum, suggesting that it was a characteristic feature of this species.

Also, it has been established that marine benthic invertebrates from Antarctic and sub-Antarctic waters have an interesting anti-tumoral potential (Reyes et al., 2008; Taboada et al., 2010). This work is the largest study of this kind carried out in the area and produced very promising results for phyla such as Chordata, Porifera, and Cnidaria, among others. We also obtained good results for a few species that showed high potential anti-inflammatory activity, and this is still work in progress.

To conclude, the research group is trying to establish the chemical interactions in Antarctic marine benthic ecosystems. A preliminary approach has been published recently (Figuerola et al., 2012c), although much more needs to be done to complete this map. Nowadays, the research in marine chemical ecology in Antarctica continues to grow and new data will help to further advance our knowledge on the role of chemical compounds in the Antarctic benthos. In order to successfully accomplish this task, the close collaboration among ecologists, chemists and microbiologists is essential. Also, further studies, such as those regarding antifouling and cytotoxicity activities, are needed to determine the ecological relevance of these mechanisms in Antarctic environments. Moreover, the bulk of the research in chemical ecology has been carried out on the phylum Porifera compared to the few studies carried out in other phyla, which are still quite understudied. To fully understand this "chemical network", we are expanding our studies to more types of experiments and more organisms during the development of our current project, ACTIQUIM-II.

\section{Effect of ocean acidification, temperature and $U V$ radiation in polar seaweeds - Francisco J. L. Gordillo, Elena Moreira, Benjamín Viñegla, Raquel Carmona and Carlos Jiménez}

Seaweeds are major components of polar coastal systems. Unlike other primary producers, they are present during the whole year and serve a number of functions in the ecosystem. They form habitats in which other organisms find food, protection, reproduction and nursery spots. Seaweeds are key to carbon biogeochemical cycles in these systems, and it is expected that any change in the algal community structure will propagate to other levels of the food web. Usually, large kelps dominate the Arctic rocky-shores, but they are not present in the Antarctic, where the desmarestial Hymantothallus grandifolius plays a similar role. Other Desmarestiales and a large number of Rhodophytes are also well represented in both systems.

The two polar coastal regions share some major characteristics. Temperature and light regimes are quite similar, as well as seasonal melting events of large ice masses that decrease the salinity of the water. The presence of ice in the intertidal restricts algal growth to the ice-free season. These characteristics are unique for polar regions, so that studies performed in one region are a useful reference to studies carried out in the other. But these similarities have a limit. There are also key factors differentiating both systems. In the Arctic, nutrients drop below detection limits during spring due mainly to phytoplanktonic blooms and remain low until autumn (Aguilera et al., 2002). The Antarctic, however, is considered as virtually not limited by nutrients all year-round. This is reflected in the different internal regulation and strategies of light harvesting and nutrient assimilation between species of the Arctic and the Antarctic (Korb and Gerard, 2000a), and it is expected that these two different strategies will ultimately determine the ability to survive in the face of environmental change.

Temperature is also relevant to the equilibrium concentration and the diffusion coefficients of dissolved $\mathrm{CO}_{2}$ (Falkowski and Raven, 1997), so that the effect of increased levels of $\mathrm{CO}_{2}$ on algal ecophysiology are, at least in part, temperature dependent. Higher concentrations of $\mathrm{CO}_{2}$ at low temperatures (and frequently low salinity during melting events) compensate for lower diffusion rates (Raven et al., 2002). The question is whether increasing the dissolved $\mathrm{CO}_{2}$ at the low temperature of polar regions will be enough to saturate the carboxylating rate of Rubisco. Maintaining a $\mathrm{CO}_{2}$-saturated rate of photosynthesis would require a three- to four-fold increase in Rubisco content on a surface area basis when decreasing the temperature from $25{ }^{\circ} \mathrm{C}$ to $5{ }^{\circ} \mathrm{C}$ (Raven and Geider, 1988). In temperate algae, acclimation to low temperature involves the maintenance of high concentrations of Calvin cycle enzymes (Davison, 1987; Davison and Davison, 1987; Davison et al., 1991). Since Rubisco is not saturated at current environmental levels of $\mathrm{CO}_{2}$, two other possibilities must be evaluated. One is the higher affinity for $\mathrm{CO}_{2}$ at low temperature exhibited by some Rubisco isoforms (Beardall and Roberts, 1999; Raven and Geider, 1988 ) and the other is the role played by an increased activity of external carbonic anhydrase (eCA) in polar macroalgae as compared to temperate ones reported by Gordillo et al. (2006). The conversion of $\mathrm{HCO}_{3}^{-}$ into $\mathrm{CO}_{2}$ is catalyzed by external carbonic anhydrase, and vice versa. Theoretically, the impact of low temperature on the photosynthesis of marine macrophytes should favor diffusive $\mathrm{CO}_{2}$ entry rather than the operation of the $\mathrm{CO}_{2}$-concentrating mechanism (Raven et al., 2002); however, the average value of eCA was much higher for Arctic species (Gordillo et al., 2006) than those reported for macroalgae from more temperate waters, such as those from Australia (Graham and Smillie, 1976), Scotland (Giordano and Maberly, 1989), and Southern Spain (Mercado et al., 1998). We called this 'the Arctic paradox' of the Ci uptake system (Gordillo et al., 2006). This higher eCA activity might be part of the adaptation strategy which implies a high concentration of Calvin cycle enzymes (Davison, 1987), which operates in Arctic macroalgae (Korb and Gerard, 2000b). 
An operational eCA must be relevant for subsistence at low temperature. Gordillo and his team found that incubation at high $\mathrm{CO}_{2}$ (1000 ppm) was unable to inhibit eCA activity in 7 out of 8 Antarctic species, and in 6 out of 6 Arctic species (Table 2; Gordillo et al., unpublished data), while this inhibitory effect is common in temperate and cold-temperate species (Giordano et al., 2005).

Global change also involves an increase in the penetration of solar ultraviolet-B (UVB) and ultraviolet-A (UVA) radiation to surface waters through changes in the stratospheric ozone concentration, which is particularly relevant in polar regions (Zepp et al., 2007). We found that two of the major Arctic kelp species, Saccharina latissima and Alaria esculenta, benefited from the combined presence of elevated $\mathrm{CO}_{2}$ and UVR, although with differences between them. S. latissima can be considered a more sensitive species than $A$. esculenta. The overall interactive effects of $\mathrm{UV}$ and $\mathrm{CO}_{2}$ in the photosynthetic performance of these species were shown by the observation that increased $\mathrm{CO}_{2}$ concentration prevented a number of alterations driven by UVR, mostly in pigment composition and, to a lesser extent, in electron transport rates. The species-specificity of the acclimation responses indicates that the interference of ocean acidification in the effects of increased UVR due to stratospheric ozone depletion might change the relative abundance of kelps at a given depth, and will potentially drive changes at the community level in the Arctic coastal system.

\section{Penguins as sentinels of Antarctic Marine Ecosystem: global change effects - Andrés Barbosa}

Seabirds and specifically penguins can be considered as sentinels of ocean change because of their position at the top of the food chain and the fact that they extensively use the ocean to forage and also their high population numbers (Boersma, 2008). Therefore, good knowledge about the health of the Antarctic seas can be obtained through the study of the biology of these species.

The research of this group on Antarctic penguins focuses on three species, chinstraps (Pygoscelis antarctica), gentoos (Pygoscelis papua) and Adélies (Pygoscelis adeliae). The main aim of their group is to study the effects of global change on the physiology of these species. Studies of the effects of global change on the animal species have been primarily focused on their distribution, abundance and phenology. This is mainly because these kinds of data have been collected and stored over many years and are therefore easy to access. However, physiological data are more complex to collect and long-term comparisons are difficult due to the existence of many different physiological functions with many different variables to be measured and

Table 2

Anhydrase activity of polar seaweeds under current levels of $\mathrm{CO}_{2}$ (380-390 ppm, AC) and high levels of $\mathrm{CO}_{2}$ (1000 ppm, HC) expressed as REA g ${ }^{-1}$ FW. Activity was measured by the potentiometric method (Haglund et al., 1992). Significance of inhibition by high $\mathrm{CO}_{2}$ at $P<0.05$ ( $\mathrm{n}=3$ to 6 ).

\begin{tabular}{llll}
\hline & AC & HC & Significant effect of HC \\
\hline Arctic & & & \\
Alaria esculenta & $3.6 \pm 1.2$ & $7.2 \pm 2.3$ & Increase \\
Phycodris rubens & $6.4 \pm 2.5$ & $8.3 \pm 1.2$ & None \\
Ptilota plumosa & $10.8 \pm 1.7$ & $8.9 \pm 1.1$ & None \\
Desmarestia aculeata & $3.7 \pm 0.2$ & $5.1 \pm 2.4$ & None \\
Monostroma arcta & $14.2 \pm 3.6$ & $10.9 \pm 1.2$ & None \\
Saccorhiza dermatodea & $5.4 \pm 2.6$ & $3.7 \pm 0.6$ & None \\
& & & \\
Antarctic & & & \\
Ascoseira mirabilis & $2.8 \pm 0.7$ & $2.5 \pm 1.4$ & None \\
Adenocystis utricularis & $4.7 \pm 2.6$ & $6.0 \pm 2.4$ & None \\
Desmarestia menziesii & $19.0 \pm 3.8$ & $6.1 \pm 2.8$ & Decrease \\
Porphyra endiviifolium & $5.2 \pm 2.2$ & $6.2 \pm 2.7$ & None \\
Palmaria decipiens & $1.0 \pm 0.8$ & $1.6 \pm 0.6$ & None \\
Monostroma hariotii & Undetected & Undetected & \\
Phaeurus antarcticus & $4.9 \pm 1.7$ & $4.4 \pm 2.1$ & None \\
Iridaea cordata & Undetected & Undetected & \\
\hline
\end{tabular}

with different methodologies. However, the effects of global change on animal species have a physiological basis, which should be understood to achieve a good understanding of this process. With this idea in mind, our group focuses its interest on this physiological approach based on the functioning of the immune system through host-parasite interaction. This is an emerging field of research in ecology (Owen et al., 2010).

The current project (PINGUCLIM) which participated in the International Polar Year project BIRDHEALTH operates at three levels: a) long-term, in which a database on different aspects of the physiology of penguins is being built and that will form the base for the study on global change effects; b) a biogeographical approach in which we study how natural environmental variation due to latitudinal gradients modulates the physiology of the species and how such variation occurs at this level. This approach will allow us to make predictions about how global change can affect the penguins; and c) a mechanistic level in which by means of observations and experiments we study how different factors affect the physiological functions. This is crucial to understand the long-term effects.

One of the main problems we found is that information on different birds is scarce and fragmented. That is the case on the distribution of parasite, pathogens and diseases present in penguins but also in other Antarctic seabirds (Barbosa and Palacios, 2009). Therefore, one of our main goals has been to increase the knowledge on this issue. We have described the presence/absence of parasites in the three species of penguins (Merino et al., 1997; Palacios et al., 2010; Vidal et al., 2012); the presence of different kinds of bacteria (Leon et al., unpublished data), sometimes being the first time that some organisms have been cited in these species of penguins. We described for the first time the distribution of ticks (Ixodes uriae) along the Antarctic Peninsula, being more abundant in the northern part of the Antarctic Peninsula (Barbosa et al., 2011). We have also studied the genetic structure of the different populations of this ectoparasite in the region (Mccoy et al., 2012) as well as the pattern of transmission of bacteria such as Borrelia burdogferi by the ticks.

One of the problems we found in the determination of parasite presence is that traditional parasitological techniques in some instances are not suitable for the detection of gastrointestinal parasites. To solve this problem, we are working to develop molecular probes for the most prevalent parasite species (Vidal et al., unpublished data).

In a global change scenario, it is predicted that parasites/pathogens will increase their distribution, prevalence and virulence (Harwell et al., 2002). In the case of penguins, exposure to new parasites could be due to changes in diet. This is because krill (Fig. 6), the main prey for the penguins in Antarctica, are declining due to climate change effects

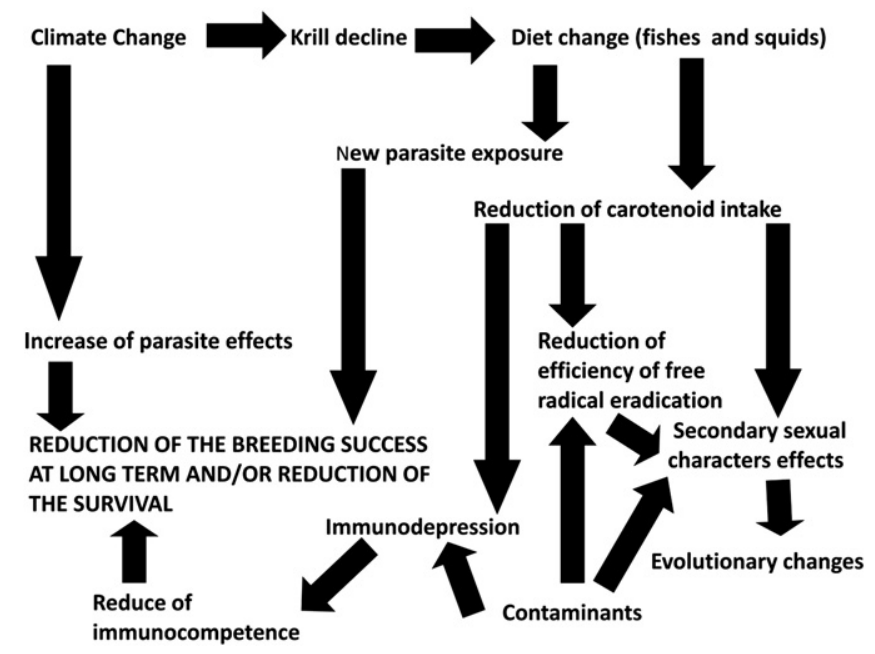

Fig. 6. Potential cascade effects of climate change on different aspects of the Antarctic penguin physiology. 
(Atkinson et al., 2004), due to the increase in human activity though tourism or research or due to the improvement in conditions which could allow parasites already established to increase their distribution ranges. It is then crucial to know the effects of parasites on the hosts. Our group is working on several experiments to address this goal (Palacios et al., 2010; Palacios et al., 2012).

The geographic variation of parasites found in Antarctic Peninsula is reflected by the geographic variation in the immunocompetence of the species. We found higher levels of immunoglobulins, which form part of the humoral immune system, in the penguin populations located in the north of the Antarctic Peninsula (Barbosa et al., 2007a). This geographic pattern is also seen in the variation in cellular immunity (D'Amico et al., unpublished data). Some of the work of the group has been addressed to unveil how immunocompetence varies between different physiological stages like breeding or molting (Palacios et al., unpublished data).

Regarding climate change, one of the immediate effects is the increase in temperatures. How penguins can manage this scenario through thermoregulation and how it could affect their immune function are other issues studied by our group. We have identified thermoregulation costs which interact with immunocompetence (Belliure et al., unpublished data).

Antarctic krill are the pivotal prey in the Antarctic ecosystem and the main prey of the three pygoscelid species, although the gentoo penguin has a wider diet spectrum (Williams, 1995). Therefore, its variation affects penguin populations and physiology (Fig. 6). We have first studied the diet of the three species in different populations by means of stable isotope analyses and we are involved in collaboration on this topic with the Portuguese group of Dr. José Xavier. Foraging studies will then be developed in the near future.

At this time, this research group has started studying the ability of penguins to detect chemical cues involved in foraging. Their results have shown for the first time that chinstrap penguins are able to detect dimethyl sulphide, a chemical compound present in the ocean and related with high productivity places (Amo et al., 2013). Antarctic krill have been declining in the Antarctic Peninsula in the last two decades (Atkinson et al., 2004) with some consequences for penguin populations, with decreases in numbers being established (Trivelpiece et al., 2011). The same pattern was found in the main study population of Deception Island where the chinstrap penguins have declined by 36\% from 1991 (Barbosa et al., 2012a). Changes in the abundance of Antarctic krill can also affect the physiological and signal functions in the case of the gentoo penguins. In this species, our group has found that the levels of carotenoids such as astaxanthin in the blood stream are related to the ingestion of Antarctic krill and vary among chick rearing and molting in adults (Barbosa et al., 2013b). Astaxanthin along with other carotenoids is involved in physiological processes such as the reduction of oxidative stress through scavenging free radicals and immunostimulation and is present in the secondary sexual traits such as the red spot that the gentoo penguin has in the beak. This signal is condition-dependent (Cuervo et al., 2009) and seems to vary geographically in relation with the abundance of Antarctic krill (Barbosa et al., 2012b) as in the case of the levels of astaxanthin (Barbosa et al., unpublished data).

Antarctica is considered as a pristine ecosystem. However, the Antarctic Peninsula, especially its northern part, is quite different due to the higher human activity present in this region. The team of Andrés Barbosa has studied the presence of heavy metals, trace elements and persistent organic pollutants (POPs) in different populations of the three species of penguin in order to obtain baseline knowledge about likely effects of pollutants on the immune system. Their results show that northern populations located in the South Shetlands and especially in King George Island have higher levels of elements such as $\mathrm{Pb}, \mathrm{Cr}$ or $\mathrm{Hg}$ (Jerez, 2012; Jerez et al., 2011). These metals show processes of bioaccumulation and signs of biomagnification (Jerez et al., 2013). Regarding POPs, our results show that PCBs, PFCs and phthalates are present in penguins from Deception Island (Jerez, 2012).
As a measure of the likely effects of contaminants and other stressors we have studied the variation among different populations of the three species of different markers e.g. heat stress proteins (HSPs) (Barbosa et al., 2007b) and erythrocytic malformations (De Mas et al., unpublished data). The results show that these markers vary at local levels probably related to the presence of specific stressors (Barbosa, unpublished data).

Finally, integrating all this information to analyze human impact on the penguins is working. As we stated above, penguins can be considered as sentinels of the marine ecosystem and they reflect environmental changes in both coastal and pelagic areas. We have studied how human activity affects different penguin physiological characteristics, particularly with regard to immunocompetence levels and stress levels by comparing penguin populations located in a highly visited rookery and in an Antarctic Specially Protected Area. The results indicate that the penguins in the highly visited rookery showed evidence of chronic stress, presence of pollutants ( $\mathrm{Pb}$ and $\mathrm{Ni}$ ), higher number of erythrocytic malformations and effects at the immunological level than the penguins from the undisturbed site (Barbosa et al., 2013a).

\section{Final considerations and future perspectives}

Polar marine ecosystems have global ecological and economic importance. They contain a unique biodiversity and play a major role in climate processes. With recent concerns of the effects of global, climatedriven changes, combined with expanding commercial interests in the polar regions (e.g. fishing in the Antarctic and oil exploration in the Arctic), marine research in these areas has became even more relevant in the past few decades (Allison et al., 2009; ICSU, 2011; Pit et al., 2012). Marine biology studies carried out by Portugal and Spain have actively contributed to the understanding of polar organisms and ecological processes, particularly in the last 20-30 years, providing valuable information to the scientific community about these still poorly known areas. This has been acknowledged within major international organizations, such as the Scientific Committee for Antarctic Research (SCAR), the International Arctic Science Council (IASC) and the Association of Polar Early Career Scientists (APECS), with various Portuguese and Spanish scientists being highly active within their Science Research Projects, expert groups and action groups.

So far, the research activities carried out by Spain and Portugal in the last two decades are unbalanced with a larger effort in the Antarctic rather than the Arctic, except for the microbial (pro- and eukaryotic) food web studies (see above). Consequently, marine research should be encouraged for the Arctic. Also, in the Antarctic, research groups from both countries must be encouraged to increase their collaborations with other countries and develop multi-disciplinary research projects (such as the Southern Ocean Observing System (SOOS) program, and within the new science research projects on life sciences within SCAR, SCAR AnT-ERA and SCAR AntECO), building strong links between researchers, instead of working in isolation. Future research in the polar regions by Iberian countries will intimately be dependent on governmental strategic vision and their willingness to support polar research in both the Arctic and Antarctic. These research activities will also require strong support from European and International collaborators (scientifically, logistically, politically and in terms of education and outreach) to ensure consistent and long-term multinational research programs and to consolidate world class research teams in these countries.

There are a range of research challenges within marine biology that need to be addressed: Rapid climate change in marine ecosystems (by collecting valuable biological data through global observation systems, as well as developing modeling tools to predict future scenarios in polar marine ecosystems at temporal and spatial scales), global climate impacts of changes in ocean circulation, loss of biodiversity and changing ecosystem patterns and ranges (including ocean acidification), global transport and contamination to the polar 
regions and consequent impacts on environments (Allison et al., 2009). Portugal and Spain marine research teams already carry out scientific projects addressing these issues (see above). More efforts should be made to address them and, simultaneously, combine all the available information obtained in the last decades and particularly in the last International Polar Year, to develop an integrative perspective at the ecosystem level and a global knowledge of the functioning of polar oceans. Today, there are still major gaps in the knowledge of the ecology of the polar regions in the context of global warming, as well as in biodiversity in both summer and winter periods (Smetacek and Nicol, 2005; Xavier and Croxall, 2007). For example, there are still enormous Antarctic areas (e.g. Amundsen Sea) in which the sessile fauna (e.g. hydroids) is still little known or completely unknown. New studies on biodiversity in these areas would increase the accuracy of the hypotheses concerning the evolution of Antarctic groups of poorly known taxa.

Future work on contaminants will focus on the evaluation of biological responses in target organisms associated with contaminant inputs during spring ice melt.

In terms of genomics applied to Antarctic organisms, the advent of cheap sequencing has produced a sea change in our abilities to understand the detail of cellular responses and identify gene pathways in environmental species. There will be an increasing amount of sequence data generated from Antarctic species, which will provide significant resources for future omic studies. Given that many of the transcripts in these non-model species are either poorly annotated or such data are absent, the next great challenge will be deciphering the function and interactions of the "unknown" genes. This will be particularly problematic in Antarctic species, where life in the cold means that metabolic rates are low, cell turnover is slow, life cycles and development times are long, etc. and therefore we may need to look at developing heterologous systems for functional assays. The impact of deciphering and understanding "life at the extremes" is numerous with all the benefits which arise from acquisition of basic knowledge about organisms and ecosystem function through to biotechnological spin-offs by exploitation of knowledge of commercial relevance. At the molecular level, this may translate into exploitation of novel molecules, molecular networks and mechanisms that have evolved for physiology and survival at low temperatures.

In relation to foraging and feeding ecology of the top predators, particularly seabirds, progress in the study of pelagic seabirds in the past 1-2 decades has, to a considerable extent, been technology-driven. The appearance of tracking devices of greater sophistication, which can be combined with other data-loggers that record activity or physiology, has allowed great progresses on the understanding of at-sea ecology and behavior of birds. Further refinement of this type of devices, and their en-masse use, will allow further progress and more hypotheses-testing, particularly when linked with climatic/oceanographic modeling (e.g. based on remotely-sensed data), with data from fisheries effort and from other sources of human disturbance. Such an interdisciplinary approach, together with increasing international collaborations allowing the expansion of the geographical scope of research (eventually making it truly global), opens promising paths for the development of the study of pelagic seabirds in the Southern Ocean and constitutes major steps towards a holistic, ecosystembased management of this prominent marine region.

Finally, many of the methods and techniques developed in the polar regions can be applied in European waters. For example, methods used in the identification of prey in the diet of top predators has already been applied in European waters, on the ecology and conservation of seabirds and fish (Paiva et al., 2010; Xavier et al., 2010; Xavier et al., 2011a; Xavier et al., 2012b). Also, the pharmacological potential of selected compounds in Antarctic organisms has been assessed (Avila et al., 2008). In all the research areas mentioned above, international collaborations are fundamental and collaborative work between Portugal and Spain is a good example and has addressed some of these research areas. Such collaborations should be encouraged to promote a strong increase in high quality science from both countries, as well as collaborating with other countries, and take polar marine research to the highest standards of science.

\section{Acknowledgments}

The research described here was mainly funded by the Portuguese and Spanish Ministries of Science and by the European Union. We would like to thank Angel Borja for their organization of the SIEBM conference in San Sebastian and all colleagues that were actively involved in conducting marine polar research in Portugal and Spain, including those that reviewed drafts of the manuscript. We also acknowledge Ana Quartin and Sónia Mendes da Silva of the Polar Office of the Fundação para a Ciência e a Tecnologia, the captain and crew of the CCGS Amundsen for their help during cruises CASES and IPY-CFL, L. Fortier and D. Barber and all the scientists who participated and helped on board, W. Arntz for participating in cruises in the R/V Polarstern, R/V Hesperides (Spain), and R/V Jan Mayen (Univ. Trömso, Norway) and having access to experimental facilities at Svalbard University, and Christian Wiencke and the Alfred Wegener Institut for polar and marine research collaborative work. We also thank the logistic support of the Marine Technology Unit (CSIC), polar ship Las Palmas, polar ship Hesperides, Spanish Antarctic base Gabriel de Castilla, Spanish Antarctic base Juan Carlos I, Byers international Refuge, Argentinean Antarctic base Carlini, Spanish Polar Committee and the Argentinean Antarctic Institute.

The work was supported by the Fundação para a Ciência e a Tecnologia (Portugal), including its Ciência program, by the Portuguese Polar Program PROPOLAR and by several grants, including the projects PTDC/MAR/099366/2008 and Pest-OE/MAR/UI0331/2011. Spanish polar research was funded by the Spanish Ministerio de Ciencia e Innovación grants POL2006-06399, CGL2007- 65453/ANT, CTM2010-17415/ANT CLG2007-28872-E/ANT "BOREAL" and REN2002-11565-E/ANT "CASES-2003/4", grant 2003ACES 00029 from DURSI, Generalitat de Catalunya, TEMPANO (REN2001-0588/ANT) to Dolors Vaqué; ESEPAC (ANT97-0273) to Susana Agusti, ICEPOS (REN2002-04165-C03-02/ ANT), ATOS (2006-2009) POL2006-00550/CTM to Carlos M. Duarte; and Arctic Tipping Points (ATP, contract \#226248) from the European Union to Paul F. Wassmann, BREDDIES Project (REN2001-2650/ANT), COUPLING Project (CTM2008-06343-C02-02) sponsored by the Spanish Ministry of Science and Technology, Xunta de Galicia-FEDER (2010/87) by the Consellería de Educación, Xunta de Galicia (CTM2009-11128ANT) funded by the Ministerio de Ciencia e Innovación of Spain and the Fondo Europeo de Desarrollo Regional (FEDER), projects CGL2007-64149/ANT and CTM2011-24007, projects REN2001-5004/ANT, CGL2004-01348, POL2006-05175, CGL2007-60369, CTM2009-08154-E and CTM201124427 and the European Development Regional Fund (that contributed to the International Polar Year project Birdhealth and PINGUCLIM project).

\section{References}

Absher, T.M., Boehs, G., Feijo, A.R., da Cruz, A.C., 2003. Pelagic larvae of benthic gastropods from shallow Antarctic waters of Admiralty Bay, King George Island. Polar Biology 26, 359-364.

ACIA, 2004. Impacts of a Warming Arctic: Arctic Climate Impact Assessment. Cambridge University Press, Cambridge, UK.

ACIA, 2005. Arctic Climate Impact Assessment. Cambridge University Press, Cambridge, UK. Agawin, N., Agustí, S., Duarte, C.M., 2002. Strong response of Antarctic picophytoplankton to experimental light and nutrient manipulation in coastal mesocosms. Aquatic Microbial Ecology 29, 161-172.

Aguilera, J., Bischof, K., Karsten, U., Hanelt, D., 2002. Seasonal variation in ecophysiological patterns in macroalgae from an Arctic fjord. II. Pigment accumulation and biochemical defence systems against high light stress. Marine Biology 140, 1087-1095.

Agustí, S., Duarte, C.M., 2000. Experimental induction of a large phytoplankton bloom in Antarctic coastal waters. Marine Ecology Progress Series 206, 73-85.

Agustí, S., Duarte, C.M., 2005. Threshold of gross primary production for planktonic metabolic balance in the Southern Ocean: an experimental test. Limnology and Oceanography 50, 1334-1339. 
Agustí, S., Duarte, C.M., Llabrés, M., Agawin, N., Kennedy, H., 2009. Response of coastal Antarctic phytoplankton to solar radiation and ammonium manipulation: an in situ mesocosm experiment. Journal of Geophysical Research - Biogeosciences 114, G01009. http://dx.doi.org/10.1029/02008JG000753.

Agustí, S., Duarte, C., Sejr, M.K., 2010. Impacts of climate warming on polar marine and freshwater ecosystems. Polar Biology 33, 1595-1598.

Albericio, F., Alvarez, M., Cuevas, C., Francesca, A., Pla, D., Tulla-Puche, J., 2009. The sea as a source of new drugs. In: Tamaki, N., Kuge, Y. (Eds.), Molecular Imaging for Integrated Medical Therapy and Drug Development. Springer, Tokyo, Japan, pp. 237-249.

Alcaraz, M., Almeda, R., Calbet, A., Saiz, E., Duarte, C.M., Lasternas, S., Agustí, S., Santiago, R., Movilla, J., Alonso, A., 2010. The role of arctic zooplankton in biogeochemical cycles: respiration and excretion of ammonia and phosphate during summer. Polar Biology 33, 1719-1731.

Allison, I., Béland, M., Alverson, K., Bell, R., Carlson, D., Cutler, P., Danell, K., Ellis-Evans, C., Fahrbach, E., Hovelsrund, G., Huber, J., Kotlyakov, V., Krupnik, I., López-Martínez, J., Mohr, T., Odmark, H., Quin, D., Rachold, V., Rapley, C., Rogne, O., Sarukhanian, E., Summerhayes, C., Yamanouchi, T., 2009. The State of Polar Research. World Meteorological Organization, Geneva.

Alonso-Sáez, L., Sánchez, O., Balagué, V., Gasol, J.M., Pedrós-Alió, C., 2008. Winter-tosummer changes in the composition and heterotrophic activity of western coastal Arctic prokaryotic assemblages. Environmental Microbiology 10, 2444-2454.

Alonso-Sáez, L., Galand, P.E., Casamayor, E.O., Pedrós-Alió, C., Bertilsson, S., 2010. High bicarbonate assimilation in the dark by Arctic bacteria. The ISME Journal 4, 1581-1590.

Alonso-Sáez, L., Waller, A.S., Mende, D.R., Bakker, K., Farnelid, H., Yager, P., Lovejoy, C., Tremblay, J.-É., Potvin, M., Heinrich, F., Estrada, M., Riemann, L., Bork, P., Pedrós-Alió, C., Bertilsson, S., 2012. Role for urea in nitrification by polar marine Archaea. Proceedings of the National Academy of Sciences of the United States of America 109, 17989-17994.

Ameneiro, J., Mouriño-Carballido, B., Parapar, J., Vázquez, E., 2012. Abundance and distribution of invertebrate larvae in the Bellingshausen Sea (West Antarctica). Polar Biology 35, 1359-1373.

Amo, L., Rodriguez-Girones, M.A., Barbosa, A., 2013. Olfactory detection of dimethyl sulphide in a krill-eating Antarctic penguin. Marine Ecology Progress Series 474, 277-285.

Anisimov, O.A., Vaughan, D.G., Callaghan, T.V., Furgal, C., Marchant, H., Prowse, T.D., Vilhjálmsson, H., Walsh, J.E., 2007. Polar regions (Arctic and Antarctic). In: Parry, M.L., Canziani, O.F., Palutikof, J.P., van der Linden, P.J., Hanson, C.E. (Eds.), Climate Change 2007: Impacts, Adaptation and Vulnerability. Contribution of Working Group II to the Fourth Assessment Report of the Intergovernmental Panel on Climate Change. Cambridge University Press, Cambridge, pp. 653-685.

Antonov, A.S., Avilov, S.A., Kalinovsky, A.I., Anastyuk, S.D., Dmitrenok, P.S., Evtushenko, E.V., Kalinin, V.I., Smirnov, A.V., Taboada, S., Ballesteros, M., Avila, C., Stonik, V.A., 2008. Triterpene glycosides from Antarctic sea cucumbers. 1. Structure of Liouvillosides A1, A2, A3, B1, and B2 from the sea cucumber Staurocucumis liouvillei: new procedure for separation of highly polar glycoside fractions and taxonomic revision. Journal of Natural Products 71, 1677-1685.

Antonov, A.S., Avilov, S.A., Kalinovsky, A.I., Anastyuk, S.D., Dmitrenok, P.S., Kalinin, V.I., Taboada, S., Bosch, A., Avila, C., Stonik, V.A., 2009. Triterpene glycosides from Antarctic sea cucumbers. 2. Structure of Achlioniceosides A(1), A(2), and A(3) from the sea cucumber Achlionice violaecuspidata (=Rhipidothuria racowitzai). Journal of Natural Products 72, 33-38.

Antonov, A.S., Avilov, S.A., Kalinovsky, A.I., Dmitrenok, P.S., Kalinin, V.I., Taboada, S. Ballesteros, M., Avila, C., 2011. Triterpene glycosides from Antarctic sea cucumbers. III. Structures of liouvillosides A4 and A5, two minor disulphated tetraosides containing 3-O-methylquinovose as terminal monosaccharide units from the sea cucumber Staurocucumis liouvillei (Vaney). Natural Product Research 25, 1324-1333.

Arnaud, P.M., López, C.M., Olaso, I., Ramil, F., Ramos-Esplá, A.A., Ramos, A., 1998. Semiquantitative study of macrobenthic fauna in the region of the South Shetland Islands and the Antarctic Península. Polar Biology 19, 160-166.

Arntz, W.E., Gili, J.M., 2001. A case for tolerance in marine ecology: let us put out the baby with the bathwater. Scientia Marina 65, 283-299.

Arntz, W.E., Thatjem, S., Gerdes, D., Gili, J.M., Gutt, J., Jacob, U., Montiel, A., Orejas, C., Teixidó, N., 2005. The Antarctic-Magellan connection: macrobenthos ecology on the shelf and upper slope, a progress report. Scientia Marina 69, 237-269.

Atkinson, A., Siegel, V., Pakhomov, E.A., Rothery, P., 2004. Long-term decline in krill stock and increase in salps within the Southern Ocean. Nature 432, 100-103.

Avila, C., 2006. Molluscan natural products as biological models: chemical ecology, histology and laboratory culture. In: Muller, Cimino, Gavagnin (Eds.), Progress in Molecular and Subcellular Biology. Subseries Marine Molecular Biotechnology. Springer-Verlag, Berlin Heidelberg, Germany, pp. 1-23.

Avila, C., Taboada, S., Núñez-Pons, L., 2008. Marine Antarctic chemical ecology: what is next? Marine Ecology 29, 1-70.

Baeseman, J., Xavier, J.C., Lantuit, H., Taylor, A., Drobot, S., Else, B., Falk-Petersen, S., Sparrow, E.B., Wagman, J., Wieler, S., 2011. Early career researcher activities during IPY. In: Krupnik, I., Allison, I., Bell, R., Cutler, P., Hik, D., Jeronimo, L.-M., Rachold, V., Sarukhanian, E., Summerhayes, C. (Eds.), Understanding Earth Polar Challenges: International Polar Year 2007-2008. University of the Arctic, Rovaniemi, Finland/ CCI Press (Printed Version), Edmonton, Alberta, Canada and ICSU/WMO Joint Committee for International Polar Year 2007-2008, pp. 511-522.

Barbosa, A., Palacios, M.J., 2009. Health of Antarctic birds: a review of their parasites, pathogens and diseases. Polar Biology 32, 1095-1115.

Barbosa, A., Merino, S., Benzal, J., Martinez, J., García-Fraile, S., 2007a. Geographic variation in immunoglobulin levels in pygoscelid penguins. Polar Biology 30, 219-225.

Barbosa, A., Merino, S., Benzal, J., Martinez, J., García-Fraile, S., 2007b. Population variability in heat shock protein among three Antarctic penguin species. Polar Biology 30.

Barbosa, A., Benzal, J., Vidal, V., D'Amico, V., Coria, N., Diaz, J., Motas, M., Palacios, M.J., Cuervo, J.J., Ortiz, J., Chitima, L., 2011. Seabird ticks (Ixodes uriae) distribution along the Antarctic península. Polar Biology 34, 1621-1624.
Barbosa, A., Benzal, J., de Leon, A., Moreno, J., 2012a. Population decline of chinstrap penguin (Pygoscelis antarctica) on Deception Island, South Shetlands, Antarctica. Polar Biology 35, 1453-1457.

Barbosa, A., Palacios, M.J., Valera, F., Martinez, A., 2012b. Geographic variation in beak coloration in gentoo penguins Pygoscelis papua. Polar Biology 35, 725-731.

Barbosa, A., De Mas, E., Benzal, J., Diaz, J.I., Motas, M., Jerez, J., Pertierra, L., Benayas, J., Justel, A., Lauzurica, P., Garcia-Peña, F.J., Serrano, T., 2013-ab. Pollution and physiological variability in gentoo penguins at two rookeries with different levels of human visitation. Antarctic Science 25, 329-338.

Barbosa, A., Palacios, M.J., Cuervo, J.J., Negro, J.J., 2013a. Plasma carotenoid depletion during fasting in moulting penguins. Journal of Ornithology 154, 559-562.

Beardall, J., Roberts, S., 1999. Inorganic carbon acquisition by two Antarctic macroalgae, Porphyra endicifolia (Rhodophyta: Bangiales) and Palmaria decipiens (Rhodophyta: Palmariales). Polar Biology 21, 310-315.

Benayas, J., Quesada, A., Barbosa, A., 2011. La investigación española en Ecología y Biología en la Antartida. Ecosistemas 20, 1-4.

Beyer, A., Matthies, M., 2001. Long-range transport potential of semivolatile organic chemicals in coupled air-water systems. Environmental Science and Pollution Research 8, 173-179.

Blunt, J.W., Copp, B.R., Keyzers, R.A., Munro, M.H.G., Prinsep, M.R., 2012. Marine natural products. Natural Product Reports 29, 144-222.

Boersma, P.D., 2008. Penguins as marine sentinels. Bioscience 58, 597-607.

Boras, J.A., Sala, M.M., Arrieta, J.M., Sà, E.L., Felipe, J., Agustí, S., Duarte, C.M., Vaqué, D. 2010. Effect of ice melting on bacterial carbon fluxes channelled by viruses and protists in the Arctic Ocean. Polar Biology 33, 1695-1707.

Bowden, D., Clarke, A., Peck, L., 2009. Seasonal variation in the diversity and abundance of pelagic larvae of Antarctic marine invertebrates. Marine Biology 156, 2033-2047.

Caldeira, K., Wickett, M.E., 2003. Anthropogenic carbon and ocean pH. Nature 425, 365

Canadell, J.G., Le Quéré, C., Raupach, M.R., Field, C.B., Buitenhuis, E.T., Ciais, P., Conway, T.J., Gillett, N.P., Houghton, R.A., Marland, G., 2007. Contributions to accelerating atmospheric $\mathrm{CO}_{2}$ growth from economic activity, carbon intensity and efficiency of natural sinks. Proceedings of the National Academy of Sciences in United States of America 104, 18866-18870.

Canário, J., Vale, C., Caetano, M., 2005. Distribution of monomethylmercury and mercury in surface sediments of the Tagus Estuary (Portugal). Marine Pollution Bulletin $50,1142-1145$

Carbone, M., Núñez-Pons, L., Castelluccio, F., Avila, C., Gavagnin, M., 2009. Illudalane sesquiterpenoids of the alcyopterosin series from the Antarctic marine soft coral Alcyonium grandis. Journal of Natural Products 72, 1357-1360.

Carbone, M., Núñez-Pons, L., Paone, M., Castelluccio, F., Avila, C., Gavagnin, M., 2012. Rossinone-related meroterpenes from the Antarctic tunicate Aplidium fuegiense. Tetrahedron 68, 3541-3544.

Catry, P., Lecoq, M., Strange, I.J., 2008. Population growth and density, diet and breeding success of striated caracaras Phalcoboenus australis on New Island, Falkland Islands. Polar Biology 31, 1167-1174.

Catry, P., Phillips, R.A., Forster, I.P., Matias, R., Lecoq, M., Granadeiro, J.P., Strange, I.J. 2010. Brood-guarding duration in black-browed albatrosses: temporal, geographical and individual variation. Journal of Avian Biology 41, 460-469.

Catry, P., Almeida, A., Lecoq, M., Granadeiro, J.P., Matias, R., 2011a. Low breeding success and sharp population decline at the largest known Falkland skua colony. Polar Biology 34, 1239-1241.

Catry, P., Forcada, J., Almeida, A., 2011b. Demographic parameters of black-browed albatrosses Thalassarche melanophris from the Falkland Islands. Polar Biology 34, 1221-1229.

Ceia, F.R., Phillips, R.A., Ramos, J.A., Cherel, Y., Vieira, R.P., Richard, P., Xavier, J.C., 2012. Short- and long-term consistency in the foraging niche of wandering albatrosses Marine Biology 159, 1581-1591.

Chen, Y.H., Miller, J.R., Francis, J.A., GL., R., Aires, F., 2003. Observed and modeled relationships among Arctic climate variables. Journal of Geophysical Research Atmosphere 108,4799

Cherel, Y., Hobson, K., 2005. Stable isotopes, beaks and predators: a new tool to study the trophic ecology of cephalopods, including giant and colossal squids. Proceedings of the Royal Society of London B 272, 1601-1607.

Clark, M.S., Thorne, M.A.S., Cardoso, J.C.R., Vieira, F.A., Power, D.M., Peck, L.S., 2010. Insights into shell deposition in the Antarctic bivalve Laternula elliptica: gene discovery in the mantle transcriptome using 454 pyrosequencing. BMC Genomics 11 362.

Clarke, A., Aronson, R.B., Crame, J.A., Gili, J.-M., Blake, D.B., 2004. Evolution and diversity of the benthic fauna of the Southern Ocean continental shelf. Antarctic Science 16, 559-568.

Collins, M.A., Rodhouse, P.G.K., 2006. Southern ocean cephalopods. Advances in Marine Biology 50, 191-265.

Collins, M.A., Xavier, J.C., Johnston, N., North, A.W., Enderlein, P., Tarling, G.A., Waluda, C., Hawker, E., Cunningham, N., 2008. Patterns in the distribution of myctophid fish in the northern Scotia Sea ecosystem. Polar Biology 31, 837-851.

Collins, M.A., Stowasser, G., Fielding, S., Shreeve, R., Xavier, J.C., Venables, H.J., Enderlein, P., Cherel, Y., Van de Putte, A., 2012. Seasonal, latitudinal and bathymetric patterns in the distribution and abundance of mesopelagic fish in the Scotia Sea. Deep-Sea Research II 59-60, 189-198.

Croxall, J.P., Gales, R., 1998. An assessment of the conservation status of albatrosses. In: Robertson, G., Gales, R. (Eds.), Albatross Biology and Conservation. Surrey Beatty, Chipping Norton, Australia, pp. 46-65.

Croxall, J.P., McCann, T.S., Prince, P.A., Rothery, P., 1988. Reproductive performance of seabirds and seals at South Georgia and Signy Island, South Orkney Islands, 1976-1987 implications for Southern Ocean monitoring studies. In: Sahrhage, D. (Ed.), Antarctic Ocean and Resources Variability. Springer-Verlag, Berlin, pp. 261-285. 
Croxall, J.P., Butchart, S.H.M., Lascelles, B., Stattersfield, A.J., Sullivan, B., Symes, A Taylor, P., 2012. Seabird conservation status, threats and priority actions: a global assessment. Birdlife Conservation International 22, 1-34.

Cuervo, J.J., Palacios, M.J., Barbosa, A., 2009. Beak colouration as a possible sexual ornament in gentoo penguin: sexual dichromatism and relationship to body condition. Polar Biology 32, 135-1314.

Cutignano, A., Zhang, W., Avila, C., Cimino, G., Fontana, A., 2011. Intrapopulation variability in the terpene metabolism of the Antarctic opisthobranch mollusc Austrodoris kerguelenensis. European Journal of Organic Chemistry 2011, 5383-5389.

Danovaro, R., Corinaldesi, C., Dell'Anno, A., Fuhrman, J.A., Middelburg, J.J., Noble, R.T. Suttle, C.A., 2011. Marine viruses and global climate change. FEMS Microbiology Reviews 35, 993-1034.

Davison, I.R., 1987. Adaptation of photosynthesis in Laminaria saccharina (Phaeophyta) to changes in growth temperatures. Journal of Phycology 23, 273-283.

Davison, I.R., Davison, J.O., 1987. The effect of growth temperature on enzymatic activities in the brown alga Laminaria saccharina. British Phycological Journal 22, 77-87.

Davison, I.R., Greene, R.M., Podolak, E.J., 1991. Temperature acclimation of respiration and photosynthesis in the brown alga Laminaria saccharina. Marine Biology 110, 449-454.

Dayton, P.K., Robilliard, G.A., Paine, R.T., Dayton, L.B., 1974. Biological accommodation in the benthic community at McMurdo Sound, Antarctica. Ecological Monographs $44,105-128$.

DeMaster, D.J., Nelson, T.M., Harden, S.L., Nittrouer, C.A., 1991. The cycling and accumulation of biogenic silica and organic carbon in Antarctic deep-sea and continenta margin environments. Marine Chemistry 35, 489-502.

Duarte, C.M., Agustí, S., Vaqué, D., Agawin, N.S., Casamayor, E., Felipe, J., Gasol, J.M. 2005. Experimental test of bacteria-phytoplankton coupling in the Southern Ocean. Limnology and Oceanography 50, 1844-1854.

Duarte, C.M., Agustí, S., Wassmann, P., Arrieta, J.M., Alcaraz, M., Coello, A., Marba, N. Hendriks, I.E., Holding, J., García-Zarandona, I., Kritzberg, E., Vaque, D., 2012. Tipping elements in the arctic marine ecosystem. Ambio 41, 44-55.

Echeveste, P., Agustí, S., Dachs, J., 2011. Cell size dependence of additive versus synergetic effects of UV radiation and PAHs on oceanic phytoplankton. Environmental Pollution 159, 1307-1316.

Falabella, V., Campagna, C., Croxall, J.P., 2009. Atlas del Mar Patagónico. Especies y espacios. Wildlife Conservation Society y BirdLife International, Buenos Aires.

Falkowski, P.G., Raven, J.A., 1997. Aquatic Photosynthesis. Blackwell Science, Malden

Figuerola, B., Ballesteros, M., Avila, C., 2012a. Description of a new species of Reteporella (Bryozoa: Phidoloporidae) from the Weddell Sea (Antarctica) and the possible functional morphology of avicularia. Acta Zoologica. http://dx.doi.org/10.1111/ j.1463-6395.2011.00531.x.

Figuerola, B., Monleón-Getino, T., Ballesteros, M., Avila, C., 2012b. Spatial patterns and diversity of bryozoan communities from the Southern Ocean: South Shetland Islands, Bouvet Island and Eastern Weddell Sea. Systematics and Biodiversity 10, 109-123.

Figuerola, B., Núñez-Pons, L., Vázquez, J., Taboada, S., Cristobo, J., Ballesteros, M., Avila C., 2012c. Chemical interactions in Antarctic marine benthic ecosystems. In: Cruzado, A. (Ed.), Marine Ecosystems. InTech Europe, Rijeka, Croatia, pp. 105-127.

Forest, A., Tremblay, J.E., Gratton, Y., Martin, J., Gagnon, J., Darnis, G., Sampei, M., Fortier, L., Ardyna, M., Gosselin, M., Hattori, H., Nguyen, D., Maranger, R., Vaque, D. Marrase, C., Pedros-Alio, C., Sallon, A., Michel, C., Kellogg, C., Deming, J., Shadwick, E., Thomas, H., Link, H., Archambault, P., Piepenburg, D., 2011. Biogenic carbon flows through the planktonic food web of the Amundsen Gulf (Arctic Ocean): a synthesis of field measurements and inverse modeling analyses. Progress in Oceanography 91, 410-436.

Freire, A.S., Absher, T.M., Cruz-Kaled, A.C., Kern, Y., Elbers, K.L., 2006. Seasonal variation of pelagic invertebrate larvae in the shallow Antarctic waters of Admiralty Bay (King George Island). Polar Biology 29, 294-302.

Galbán-Malagón, C., Berrojalbiz, N., Ojeda, M.J., Dachs, J., 2012. The oceanic biological pump modulates the atmospheric transport of persistent organic pollutants to the Arctic. Nature Communication 3. http://dx.doi.org/10.1038/ncomms1858.

Ghiglione, J.-F., Galand, P.E., Pommier, T., Pedrós-Alió, C., Maas, E.W., Bakker, K., Bertilson, S., Kirchman, D.L., Lovejoy, C., Yager, P.L., Murray, A.E., 2012. Pole to pole biogeography of surface and deep marine bacterial communities. Proceedings of the National Academy of Sciences of the United States of America 109, 17633-17638.

Gili, J.-M., Coma, R., 1998. Benthic suspension feeders: their paramount role in littora marine food webs. Trends in Ecology \& Evolution 13, 316-321.

Gili, J.-M., Coma, R., Orejas, C., López-González, P.J., Zabala, M., 2001. Are Antarctic suspension-feeding communities different from those elsewhere in the world? Polar Biology 24, 473-485.

Gili, J.-M., Arntz, W.E., Palanques, A., Orejas, C., Clarke, A., Dayton, P.K., Isla, E., Teixidó N., Rossi, S., López-González, P.J., 2006a. A unique assemblage of epibenthic sessile suspension feeders with archaic features in the high-Antarctic. Deep Sea Research II 53, 1029-1052.

Gili, J.-M., Rossi, S., Pagès, F., Orejas, C., Teixidó, N., López-González, P.J., Arntz, W.E. 2006b. A new trophic link between the pelagic and benthic systems on the Antarctic shelf. Marine Ecology Progress Series 322, 43-49.

Giordano, M., Maberly, S.C., 1989. Distribution of carbonic anhydrase in British marine macroalgae. Oecologia 81, 534-539.

Giordano, M., Beardall, J., Raven, J.A., 2005. $\mathrm{CO}_{2}$ concentrating mechanisms in algae: mechanisms, environmental modulation, and evolution. Annual Review of Plant Biology 56, 99-131.

Gordillo, F.J.L., Aguilera, J., Jiménez, C., 2006. The response of nutrient assimilation and biochemical composition of Arctic seaweeds to a nutrient input in summer. Journal of Experimental Botany 57, 2661-2671

Graham, D., Smillie, R.M., 1976. Carbonate dehydratase in marine organisms of the Great Barrier Reef. Australian Journal of Plant Physiology 3, 113-119.
Granadeiro, J.P., Phillips, R.A., Brickle, P., Catry, P., 2011. Albatrosses following fishing vessels. How badly hooked are they on an easy meal? PloS One 6, e17467.

Griffiths, H.J., Barnes, D.K.A., Linse, K., 2009. Towards a generalized biogeography of the Southern Ocean benthos. Journal of Biogeography 36, 162-177.

Gutt, J., Barratt, I., Domack, E., d'Udekem d'Acoz, C., Dimmler, W., Grémare, A., Heilmayer, O., Isla, E., Janussen, D., Jorgensen, E., Kock, K.-H., Lehnert, L.S., López-González, P.J., Langner, S., Linse, K., Manjón-Cabeza, M.E., Meißner, M., Montiel, A., Raes, M., Robert, H., Rose, A., Sañé, E., Saucède, T., Scheidat, M., Schenke, H.-W., Seiler, J., Smith, C., 2011. Biodiversity change after climate-induced ice-shelf collapse in the Antarctic. Deep Sea Research II 58, 74-83.

Haglund, K., Björk, M., Ramazanov, Z., García-Reina, G., Pedersén, M., 1992. Role of carbonic anhydrase in photosynthesis and inorganic carbon assimilation in the red alga Gracilaria tenuistipitata. Planta 187, 275-281.

Harwell, C.D., Mitchell, C.E., Ward, J.R., Altizer, S., Dobson, A.P., Ostfeld, R.S., Samuel, M.D., 2002. Climate warming and disease risk for terrestrial and marine biota. Science 296, 2158-2163.

Hedgpeth, J.W., 1969. Introduction to Antarctic zoogeography, distribution of selected groups of marine invertebrates in waters south of $35^{\circ} \mathrm{S}$ latitude. Antarctic Mapping Folio Series 1-9.

ICSU, 2011. SCAR Antarctic Science and Policy Advice in a Changing World: Strategic Plan 2011-2016. SCAR, Scott Polar Research Institute, Cambridge, UK.

Isla, E., Gerdes, D., Palanques, A., Gili, J.-M., Arntz, W., 2006a. Particle fluxes and tides near the continental ice edge on the eastern Weddell Sea shelf. Deep Sea Research II 53, 866-874

Isla, E., Rossi, S., Palanques, A., Gili, J.-M., Gerdes, D., Arntz, W., 2006b. Biochemical composition of marine sediment from the eastern Weddell Sea (Antarctica): high nutritive value in a high benthic-biomass environment. Journal of Marine Systems 60, 255-267.

Isla, E., Gerdes, D., Palanques, A., Arntz, W.E., 2009. Downward particle fluxes, wind and a phytoplankton bloom over a polar continental shelf: a stormy impulse for the biological pump. Marine Geology 259, 59-72.

Isla, E., Gerdes, D., Rossi, S., Fiorillo, I., Sañé, E., Gili, J.-M., Arntz, W.E., 2011. Biochemical characteristics of surface sediments on the eastern Weddell Sea continental shelf, Antarctica: is there any evidence of seasonal patterns? Polar Biology 34, 1125-1133.

Jerez, S., 2012. Los pingüinos: bioindicadores de la contaminación ambiental en la península Antártica e islas asociadas. PhD Thesis Universidad de Murcia.

Jerez, S., Motas, M., Palacios, M.J., Valera, F., Cuervo, J.J., Barbosa, A., 2011. Concentration of trace elements in feathers of three Antarctic penguins: geographical and interspecific differences. Environment Pollution 159, 2412-2419.

Jerez, S., Motas, M., Benzal, J., Diaz, J., Vidal, V., D'Amico, V., Barbosa, A., 2013. Distribution of metals and trace elements in adult and juvenile penguins from the Antarctic península area. Environment Science Pollution Research 20, 3300-3311.

Kaiser, B., Zicus, S., Allen, B., 2010. Polar Science and Global Climate: An International Resource for Education \& Outreach. Pearson Custom Publishing.

Kang, J.S., Kang, S.H., Lee, J.H., Lee, S., 2002. Seasonal variation of microalgal assemblages at a fixed station in King George Island, Antarctica, 1996. Marine Ecology Progress Series 229, 19-32.

König, G., Kehraus, S., Seibert, S.F., Abdel-Lateff, A., Müller, D., 2006. Natural products from marine organisms and their associated microbes. ChemBioChem 7, 229-238.

Korb, R.E, Gerard, V.A, 2000a. Effects of concurrent low temperature and low nitrogen supply on polar and temperate waters. Marine Ecology Progress Series 198, 73-82.

Korb, R.E., Gerard, V.A., 2000b. Nitrogen assimilation characteristics of polar seaweeds from differing nutrient environment. Marine Ecology Progress Series 198, 83-92.

Kroeker, K.J., Kordas, R.L., Crim, R.N., Singh, G.G., 2010. Meta-analysis reveals negative yet variable effects of ocean acidification on marine organisms. Ecology Letters 13, 1419-1434.

Krupnik, I., Allison, I., Bell, R., Cutler, P., Hik, D., López-Martinez, J., Rachold, V., Sarukhanian, E., Summerhayes, C., 2011. Understanding Earth's Polar Challenges: International Polar Year 2007-2008. University of the Arctic/CCI Press, Rovaniemi, Finland.

Lara, E., Arrieta, J.M., Garcia-Zarandona, I., Boras, J.A., Duarte, C.M., Agusti, S., Wassmann, P.F., Vaqué, D., 2013. Experimental evaluation of the warming effect on viral, bacterial and protistan communities in two contrasting Arctic systems. Aquatic Microbial Ecology (in press)

Lasternas, S., Agusti, S., 2010. Phytoplankton community structure during the record Arctic ice-melting of summer 2007. Polar Biology 33, 1709-1717.

Lebar, M.D., Heimbegner, J.L., Baker, B.J., 2007. Cold-water marine natural products. Natural Product Reports 24, 774-797.

López-González, P.J., Gili, J.-M., 2000. A new octocorallian genus (Cnidaria: Anthozoa) from Antarctic waters. Polar Biology 23, 452-458.

López-González, P.J., Gili, J.-M., 2001. Rosgorgia inexpectata, new genus and new species of Subergorgiidae (Cnidaria, Octocorallia) from off the Antarctic Peninsula. Polar Biology 24, 122-126.

López-González, P.J., Gili, J.-M., 2005. Two new dimorphic soft-coral species (Anthozoa: Octocorallia) from Antarctica. Hydrobiologia 544, 143-153.

López-González, P., Gili, J.-M., Orejas, C., 2002. A new primnoid genus (Anthozoa: Octocorallia) from the Southern Ocean. Scientia Marina 66, 383-397.

Lovejoy, C., Vincent, W.F., Bonilla, S., Roy, S., Martineau, M.J., Terrado, R., Potvin, M., Massana, R., Pedrós-Alió, C., 2007. Distribution, phylogeny, and growth of coldadapted picoprasinophytes in Arctic Seas. Journal of Phycology 43, 78-89.

Macdonnald, R.W., Harner, T., Fyfe, J., 2005. Recent climate change in the Arctic and its impact on contaminant pathways and interpretation of temporal trend data. The Science of the Total Environment 342, 5-86.

Marques, A.C., Peña Cantero, A.L., 2010. Areas of endemism in the Antarctic - a case study of the benthic hydrozoan genus Oswaldella (Cnidaria, Kirchenpaueriidae). Journal of Biogeography 37, 617-623.

Matias, R., Catry, P., 2008. The diet of feral cats on New Island, Falkland, Islands, and possible impact on breeding seabirds. Polar Biology 31, 609-616. 
McClintock, J.B., Amsler, C.D., Baker, B., 2010. Overview of the chemical ecology of benthic marine invertebrates along the western Antarctic Peninsula. Integrative and Comparative Biology 50, 967-980.

Mccoy, K.D., Beis, P., Barbosa, A., Cuervo, J.J., Fraser, W.R., Gonzalez-Solis, J., Jourdain, E., Poisbleau, M., Quillfeldt, P., Leger, E., Dietrich, M., 2012. Population genetic structure and colonisation of the Western Antarctic Peninsula by seabird ticks Ixodes uriae. Marine Ecology Progress Series 459, 109-120.

Mercado, J.M., Gordillo, F.J.L., Figueroa, F.L., Niell, F.X., 1998. External carbonic anhydrase and affinity for inorganic carbon in intertidal macroalgae. Journal of Experimental Marine Biology and Ecology 221, 209-220.

Merino, S., Barbosa, A., Moreno, J., Potti, J., 1997. Absence of haematozoa from a wild chinstrap penguin Pygoscelis antarctica population. Polar Biology 18, 227-228.

Newman, D.J., Cragg, G.M., 2007. Natural products as sources of new drugs over the last 25 years. Journal of Natural Products 70, 461-477.

Núñez-Pons, L., Carbone, M., Paris, D., Melck, D., Ríos, P., Cristobo, J., Castelluccio, F. Gavagnin, M., Avila, C., 2012a. Chemo-ecological studies on hexactinellid sponges from the Southern Ocean. Naturwissenschaften 99, 353-368.

Núñez-Pons, L., Carbone, M., Vázquez, J., Rodríguez, J., Nieto, R.M., Varela, M.M., Gavagnin, M., Avila, C., 2012b. Natural products from Antarctic colonial ascidians of the genera Aplidium and Synoicum: variability and defensive role. Marine Drugs 10, 1741-1764.

Núñez-Pons, L., Rodríguez-Arias, M., Gómez-Garreta, A., Ribera, M.A., Avila, C., 2012c. Feeding deterrency in Antarctic marine organisms: bioassays with the omnivore lyssianasid amphipod Cheirimedon femoratus. Marine Ecology Progress Series 462, 163-174.

Orejas, C., Gili, J.-M., Arntz, W.E., Ros, J.D., López-González, P.J., Teixidó, N., Pinto, P., 2000. Benthic suspension feeders, key players in Antarctic marine ecosystems. Contributions to Science 1, 299-311.

Orejas, C., López-González, P.J., Gili, J.-M., Teixidó, N., Gutt, J., Arntz, W.E., 2002. Distribution and reproductive ecology of the Antarctic octocoral Ainigmaptilon antarcticus in the Weddell Sea. Marine Ecology Progress Series 231, 101-114.

Orejas, C., Gili, J.-M., Arntz, W.E., 2003. Role of small-plankton communities in the diet of two Antarctic octocorals (Primnoisis antarctica and Primnoella sp.). Marine Ecology Progress Series 250, 105-116.

Orr, J.C., Fabry, V.J., Aumont, O., Bopp, L., Doney, S.C., Feely, R.A., Gnanadesikan, A., Gruber, N., Ishida, A., Joos, F., Key, R.M., Lindsay, K., Maier-Reimer, E., Matear, R., Monfray, P., Mouchet, A., Najjar, R.G., Plattner, G.-K., Rodgers, K.B., Sabine, C.L., Sarmiento, J.L., Schlitzer, R., Slater, R.D., Totterdell, I.J., Weirig, M.-F., Yamanaka, Y., Yool, A., 2005. Anthropogenic ocean acidification over the twenty-first century and its impact on calcifying organisms. Nature 437, 681-686.

Owen, J.P., Nelson, A.C., Clayton, D.H., 2010. Ecological immunology of bird-ectoparasite systems. Trends in Parasitology 26, 530-539.

Paiva, V.H., Xavier, J.C., Geraldes, P., Ramirez, I., Ramos, J.A., Garthe, S., 2010. Foraging ecology of Cory's shearwaters in different ecological environments of the North Atlantic. Marine Ecology Progress Series 410, 257-268.

Palacios, M.J., Barbosa, A., Pedraza-Diaz, S., Ortega-Mora, L.M., Valera, F., Cuervo, J.J., Benzal, J., De La Cruz, C., 2010. Apparent absence of Cryptosporidium, Giardia and Toxoplasma gondii in three species of penguins along the Antarctic Peninsula. Antarctic Science 22, 265-270.

Palacios, M.J., Valera, F., Barbosa, A., 2012. Experimental assessment of the effects of gastrointestinal parasites on offspring quality in chinstrap penguins (Pygoscelis antarctica). Parasitology 139, 819-824.

Palanques, A., Isla, E., Puig, P., Sanchez-Cabeza, J.A., Masqué, P., 2002. Annual evolution of downward particle fluxes in the Western Bransfield Strait (Antarctica) during the FRUELA experiment. Deep Sea Research II 49, 903-920.

Paul, V.J., Arthur, K.E., Ritson-Williams, R., Ross, C., Sharp, K., 2007. Chemical defenses: from compounds to communities. The Biological Bulletin 213, 226-251.

Paul, V.J., Ritson-Williams, R., Sharp, K., 2011. Marine chemical ecology in benthic environments. Natural Product Reports 28, 345-387.

Pearse, J.S., Bosch, I., 2002. Photoperiodic regulation of gametogenesis in the Antarctic sea star Odontaster validus Koehler: evidence for a circannual rhythm modulated by light. Invertebrate Reproduction and Development 41, 73-81.

Pearse, J.S., Lockhart, S.J., 2004. Reproduction in cold water: paradigm changes in the 20th century and a role for cidaroid sea urchins. Deep Sea Res Part II 51, 1533-1549.

Pearse, J.S., McClintock, J.B., Bosch, I., 1991. Reproduction of Antarctic benthic marine invertebrates: tempos, modes, and timing. American Zoologist 31, 65-80.

Peña Cantero, A.L., García Carrascosa, A.M., 1999. Biogeographical distribution of the benthic thecate hydroids collected during the Spanish "Antártida 8611" expedition and comparison between Antarctic and Magellan benthic hydroid faunas. Scientia Marina 63, 209-218.

Peña Cantero, A.L., Marques, A.C., 1999. Phylogenetic analysis of the Antarctic genus Oswaldella Stechow, 1919 (Hydrozoa, Leptomedusae, Kirchenpaueriidae). Contributions to Zoology 68, 83-93.

Peña Cantero, A.L., Sentandreu, V., Latorre, A., 2010. Phylogenetic relationships of the endemic Antarctic benthic hydroids (Cnidaria, Hydrozoa): what does the mitochondrial 16S rRNA tell us about it? Polar Biology 33, 41-57.

Phillips, R.A., Croxall, J.P., Silk, J.R.D., Briggs, D.R., 2008. Foraging ecology of albatrosses and petrels from South Georgia: two decades of insights from tracking technologies. Aquatic Conservation: Marine and Freshwater Ecosystems 17, S6-S21.

Pilling, G.M., Purves, M.G., Daw, T.M., Agnew, D.A., Xavier, J.C., 2001. The stomach contents of Patagonian toothfish around South Georgia (South Atlantic). Journal of Fish Biology 59, 1370-1384.

Pit, M., Bowden, S., Rachold, V., 2012. IASC 2012 Bulletin. International Arctic Science Committee, Potsdam, Germany.

Poulin, E., Palma, A.T., Féral, J.-P., 2002. Evolutionary versus ecological success in Antarctic benthic invertebrates. Trends in Ecology \& Evolution 17, 218-222.

Ramos, A., 1999. The megazoobenthos of the Scotia arc islands. Scientia Marina 63, 171-182.
Raven, J.A., Geider, R.J., 1988. Temperature and algal growth. The New Phytologist 110, 441-461.

Raven, J.A., Johnston, A.M., Kübler, J.E., Korb, R., Mcinroy, S.G., Handley, L.L., Scrimgeour C.M., Walker, D.I., Beardall, J., Clayton, M.N., Vanderklift, M., Fredriksen, S., Dunton, K., 2002. Seaweeds in the cold seas: evolution and carbon acquisition. Annals of Botany 90, 525-536.

Ré, P., Almeida, A.J., Biscoito, M., 2001. Luiz Vieira Caldas Saldanha: passion for the sea Boletim do Museu Municipal do Funchal 6, 5-13.

Regaudie-de-Gioux, A., Duarte, C.M., 2011. Planktonic metabolism in the Greenland Sea during the polar summer of 2007. Polar Biology 33, 1651-1660.

Reyes, F., Fernández, R., Rodríguez, A., Francesch, A., Taboada, S., Avila, C., 2008. Aplicyanins A-F, new cytotoxic bromoindole derivates from the marine tunicate Aplydium cyaneum. Tetrahedron 64, 5119-5123.

Ries, J.B., Cohen, A.L., McCorkle, D.C., 2009. Marine calcifiers exhibit mixed responses to $\mathrm{CO}_{2}$-induced ocean acidification. Geology 37, 1131-1134.

Roberts, J., Xavier, J.C., Agnew, D.J., 2011. The diet of toothfish species Dissostichus eleginoides and Dissostichus mawsoni with overlapping distributions around the South Sandwich Ilsands, Southern Ocean. Journal of Fish Biology 79, 138-154.

Rodríguez, E., López-González, P.J., Gili, J.-M., 2007. Biogeography of Antarctic Sea Anemones (Anthozoa, Actinairia): what do they tell us about the origin of the Antarctic benthic fauna? Deep Sea Research II 54, 1876-1904.

Sahade, R.J., Tatian, M., Kowalke, J., Kuhne, S., Esnal, G.B., 1998. Benthic faunal associations on soft substrates at Potter Cove, King George Island, Antarctica. Polar Biology 19, 85-91.

Sáiz-Salinas, J.I., Ramos, A., García, F.J., Troncoso, J.S., San Martín, G., Sanz, C., Palacín, C., 1997. Quantitative analysis of macrobenthic soft bottom assemblages in South Shetland waters (Antarctica). Polar Biology 17, 393-400.

Sala, M.M., Terrados, R., Lovejoy, C., Unrein, F., Pedrós-Alió, C., 2008. Metabolic diversity of heterotrophic bacterioplankton over winter and spring in the coastal Arctic Ocean. Environmental Microbiology 10, 942-949.

Sala, M.M., J.M., A., J.A., B., Duarte, C.M., Vaque, D., 2010. The impact of ice melting on bacterioplankton in the Arctic Ocean. Polar Biology 33, 1683-1694.

Saldanha, L., 1983. Aspectos biológicos. Separata do Boletim da Sociedade de Geografia de Lisboa 79-91.

Saldanha, L., 1991. Aspects de la zonation benthique dans le cratère de Lîle St. Paul (Océan Indien). Actas do V Simposio Ibérico de Estudios del Bentos Marino 1, 19-26.

Saldanha, L., Almeida, A., Ledoyer, M., Ré, P., 1990a. Aspects de la zonation benthique dans le cratere deLíle St. Paul. Les publications de la mission de recherche des terres australes et Antarctiques Françaises 86, 127-131.

Saldanha, L., Almeida, A., Ledoyer, M., Ré, P., 1990b. Operations realisees dans le cratere de L Île Saint-Paul au cours de la campagne MD 50/Jasus. Les publications de la mission de recherche des terres australes et Antarctiques Françaises 120-123.

Sañé, E., Isla, E., Grémare, A., Gutt, J., Vetion, G., 2011. Pigments in sediments beneath a recently collapsed ice shelves: the case of Larsen A and B shelves. Antarctic Peninsula Journal of Sea Research 65, 94-102.

Sañé, E., Isla, E., Gerdes, D., Montiel, A., Gili, J.-M., 2012a. Benthic macrofauna assemblages and biochemical properties of sediments in two Antarctic regions differently affected by climate change. Continental Shelf Research 35, 53-63.

Sañé, E., Isla, E., Pruski, A.M., Bárcena, M.A., Vétion, G., DeMaster, D., 2012b. Diatom valve distribution and sedimentary fatty acid composition in Larsen Bay, Eastern Antarctic Peninsula. Continental Shelf Research 31,1161-1168.

Sangrá, P., Gordo, C., Hernández-Arencibia, M., Marrero-Díaz, A., Rodríguez-Santana, A. Stegner, A., Martínez-Marrero, A., Pelegrí, J.L., Pichon, T., 2011. The Bransfield current system. Deep Sea Research Part I 58, 390-402.

Schiermeier, Q., 2009. In from the cold. Nature 457, 1072-1077.

Sewell, M.A., 2005. Examination of the meroplankton community in the south-western Ross Sea, Antarctica, using a collapsible plankton net. Polar Biology 28, 119-131.

Sherr, E.B., Sherr, B.F., Wheeler, P.A., K., T., 2003. Temporal and spatial variation in stocks of autotrophic and heterotrophic microbes in the upper water column of the central Arctic Ocean. Deep Sea Research I 50, 557-571.

Shreeve, R., Peck, L.S., 1995. Distribution of pelagic larvae of benthic marine invertebrates in the Bellingshausen Sea. Polar Biology 15, 369-374.

Smetacek, V., Nicol, S., 2005. Polar ocean ecosystems in a changing world. Nature 437 362-368.

Stanwell-Smith, D.P. Peck, L.S., Clarke, A. Murray, A., Todd, C., 1999. The distribution, abundance and seasonality of pelagic marine invertebrate larvae in the maritime Antarctic. Philosophical Transactions of the Royal Society 354, 471-484.

Taboada, S., 2012. Antarctic Marine Benthic Invertebrates: Chemical Ecology, Bioactivity and Biodiversity. (PhD Thesis) University of Barcelona.

Taboada, S., García-Fernández, L.F., Bueno, S., Vazquez, J., Cuevas, C., Avila, C., 2010 Antitumoural activity in Antarctic and sub-Antarctic benthic organisms. Antarctic Science 22, 494-507.

Taboada, S., Doner, S., Blake, J.A., Avila, C., 2012a. A new species of Cirratulus (Annelida: Polychaeta) described from a shallow-water whale bone in Antarctica. Zootaxa 3340, 59-68.

Taboada, S., Núñez-Pons, L., Avila, C., 2012b. Feeding repellence of Antarctic and subAntarctic benthic invertebrates against the omnivorous sea star Odontaster validus. Polar Biology. http://dx.doi.org/10.1007/s00300-00012-01234-z.

Tavares, S., Xavier, J.C., Phillips, R.P., Pereira, M.E., Pardal, M.A., 2013. Influence of age, sex and breeding status on mercury accumulation patterns in wandering albatrosses Diomedea exulans. Environmental pollution 242 (in press).

Teixidó, N., Garrabou, J., Arntz, W.E., 2002. Spatial pattern quantification of Antarctic benthic communities using landscape indices. Marine Ecology Progress Series 242, 1-14.

Teixidó, N., Garrabou, J., Gutt, J., Arntz, W.E., 2004. Recovery in Antarctic benthos after iceberg disturbance: trends in benthic composition, abundance and growth forms. Marine Ecology Progress Series 278, 1-16. 
Teixidó, N., Gili, J.-M., Uriz, M.J., Gutt, J., Arntz, W., 2006. Observations of sexual reproductive strategies in hexactinellid sponges from ROV video records. Deep Sea Research II 53, 972-984.

Teixidó, N., Garrabou, J., Gutt, J., Arntz, W.E., 2007. Impact of iceberg disturbance and successional spatial patterns: the case of the deep Antarctic benthic communities. Ecosystems 10, 143-158.

Tovar-Sánchez, A., Duarte, C.M., Alonso, J.C., Lacorte, S., Tauler, R., Galván-Malagón, C., 2010. Impact of metals and nutrients released from melting multiyear Arctic Sea ice. Journal of Geophysical Research. http://dx.doi.org/10.1029/2009JC005685.

Trivelpiece, W.Z., Hinke, J.T., Miller, A.K., Reiss, C.S., Trivelpiece, S.G., Watters, G.M. 2011. Variability in krill biomass links harvesting and climate warming to penguin population changes in Antarctica. PNAS 108, 7625-7628.

Turner, J., Bindschadler, R., Convey, P., di Prisco, G., Fahrbach, E., Gutt, J., Hodgson, D. Mayewski, P., Summerhayes, C., 2009. Antarctic Climate Change and the Environment. Scientific Committee for Antarctic Research, Cambridge, UK.

Uriz, M.J., Gili, J.-M., Orejas, C., Pérez-Porro, A.R., 2011. Do bipolar distribution exist in marine sponges? Stylocordyla chupachups sp. nv. (Porifera: Hadromerida) from the Weddell Sea (Antarctic) previously reported as S. borealis (Lovén, 1868). Polar Biology 34, 243-255.

Vale, C., Canário, J., Caetano, M., Lavrado, J., Brito, P., 2008. Estimation of the antrophogenic fraction of elements in surface sediments of the Tagus estuary (Portugal). Marine Pollution Bulletin 56, 1353-1376.

Vaqué, D., Agustí, S., C.M., D., 2004. Response of bacterial grazing rates to experimental manipulation of an Antarctic coastal nanoflagellate community. Aquatic Microbial Ecology 36, 41-52.

Vaqué, D., Guadayol, O., Peters, F., Felipe, J., Angel-Ripoll, L., Terrado, R., Lovejoy, C. Pedrós-Alió, C., 2008. Seasonal changes in planktonic bacterivory rate under the ice-covered coastal Arctic Ocean. Limnology and Oceanography 53, 2427-2438.

Vaqué, D., Guadayol, O., Peters, F., Felipe, J., Malits, A., Pedrós-Alió, C., 2009. Differentia response of grazing and bacterial heterotrophic production to experimental warming in Antarctic waters. Aquatic Microbial Ecology 54, 101-112.

Vázquez, E., Ameneiro, J., Putzeys, S., Gordo, C., Sangrà, P., 2007. Distribution of meroplankton communities in the Bransfield Strait, Antarctica. Marine Ecology Progress Series 338, 119-129.

Vidal, V., Ortiz, J., Diaz, J.I., Ruiz de Ybañez, M.R. Amat, M.T. Palacios, M.., Benzal, J. Valera, F., De la Cruz, C., Motas, M., Barbosa, A., 2012. Gastrointestinal parasites in chinstrap penguins from Deception Island, South Shetlands, Antarctica. Parasitology Research 111, 723-727.

Vincent, W., Pedrós-Alió, C., 2008. Sea ice and life in a river-influenced Arctic shelf ecosystem. Journal of Marine Systems 74, 739-740.

Vincent, W., Pedrós-Alió, C., Suttle, C., Lovejoy, C., Deming, J., Osburn, C., Lesak, L. Xie, H., Babin, M., Wilmotte, A., 2008. Microbial communities and carbon fluxes. In: Fortier, L., Barber, D., Michaud, J. (Eds.), On Thin Ice. A Synthesis of the Canadian Arctic Shelf Exchange Study (CASES). Aboriginal Issues Press, Winnipeg, Manitoba, Canada, pp. 85-99.

Wassmann, P., Duarte, C.M., Agusti, S., Sejr, M.K., 2011. Footprints of climate change in the Arctic marine ecosystem. Global Change Biology 17, 1235-1249.

Williams, T.D., 1995. The Penguins. Oxford University Press.

Xavier, J.C., Cherel, Y., 2009. Cephalopod Beak Guide for the Southern Ocean. British Antarctic Survey

Xavier, J.C., Croxall, J.P., 2005. Sexual differences in foraging behaviour and diets: a case-study of wandering albatrosses. In: Ruckstuhl, K., Nehaus, P. (Eds.), Sexual Segregation in Vertebrates. Cambridge University Press, Cambridge, pp. 74-91.

Xavier, J.C., Croxall, J.P., 2007. Predator-prey interactions: why do larger albatrosses feed on bigger squid? Journal of Zoology (London) 271, 408-417.

Xavier, J.C., Rodhouse, P.G., Trathan, P.N., Wood, A.G., 1999. A Geographical Information System (GIS) atlas of cephalopod distribution in the Southern Ocean. Antarctic Science 11, 61-62.

Xavier, J.C., Croxall, J.P., Rodhouse, P.G.K., 2002a. Unusual occurrence of Illex argentinus (Cephalopoda: Ommastrephidae) in the diet of the albatrosses breeding at Bird Island, South Georgia. Bulletin of Marine Science 71, 1109-1112.
Xavier, J.C., Rodhouse, P.G., Purves, M.G., Daw, T.M., Arata, J., Pilling, G.M., 2002b. Distribution of cephalopods recorded in the diet of Patagonian toothfish (Dissostichus eleginoides) around South Georgia. Polar Biology 25, 323-330.

Xavier, J.C., Croxall, J.P., Reid, K., 2003a. Inter-annual variation in the diet of two albatross species breeding at South Georgia: implications for breeding performance. Ibis $145,593-610$.

Xavier, J.C., Croxall, J.P., Trathan, P.N., Rodhouse, P.G., 2003b. Inter-annual variation in the cephalopod component of the diet of wandering albatrosses Diomedea exulans breeding at Bird Island, South Georgia. Marine Biology 142, 611-622.

Xavier, J.C., Croxall, J.P., Trathan, P.N., Wood, A.G., 2003c. Feeding strategies and diets of breeding grey-headed and wandering albatrosses at South Georgia. Marine Biology 143, 221-232.

Xavier, J.C., Trathan, P.N., Croxall, J.P., Wood, A.G., Podestá, G.P., Rodhouse, P.G., 2004. Foraging ecology and interactions with fisheries of wandering albatrosses at South Georgia. Fisheries Oceanography 13, 324-344.

Xavier, J.C., Croxall, J.P., Cresswell, K.A., 2005. Boluses: an effective method to assess the proportions of cephalopods in the diet of albatrosses. The Auk 122, 1182-1190.

Xavier, J.C., Geraint, G.A., Croxall, J.P., 2006a. Determining large scale distribution of pelagic cephalopods, fish and crustaceans in the South Atlantic from wandering albatross (Diomedea exulans) foraging data. Ecography 29, 260-272.

Xavier, J.C., Vieira, G.T., Canário, A., 2006b. Portuguese Science Strategy for the International Polar Year. Centre of Marine Sciences. University of Algarve (42 pp.).

Xavier, J.C., Clarke, M.R., Magalhães, M.C., Stowasser, G., Blanco, C., Cherel, Y., 2007a. Current status of using beaks to identify cephalopods: III International Workshop and Training Course on Cephalopod Beaks, Faial Island, Azores, April 2007. Arquipélago - Life and Marine Sciences 24, 41-48.

Xavier, J.C., Wood, A.G., Rodhouse, P.G., Croxall, J.P., 2007b. Interannual variations in cephalopod consumption by albatrosses at South Georgia: implications for future commercial exploitation of cephalopods. Marine and Freshwater Research 58, 1136-1143.

Xavier, J.C., Cherel, Y., Assis, C.A., Sendão, J., Borges, T.C., 2010. The feeding ecology of Conger eels (Conger conger) in the North-east Atlantic. Journal of the Marine Biological Association of the United Kingdom 90, 493-501.

Xavier, J.C., Magalhães, M.C., Mendonça, A.S., Antunes, M., Carvalho, N., Machete, M., Santos, R.S., Paiva, V.H., Hamer, K.C., 2011a. Changes in diet of Cory's Shearwaters Calonectris diomedea breeding in the Azores. Marine Ornithology 39, 129-134.

Xavier, J.C., Phillips, R.A., Cherel, Y., 2011b. Cephalopods in marine predator diet assessments: why identifying upper and lower beaks is important. ICES Journal of Marine Science 68, 1857-1864.

Xavier, J.C., Cherel, Y., Roberts, J., Piatkowski, U., 2012a. How do cephalopods become available to seabirds: can fish gut contents from tuna fishing vessels be a major food source of deep-dwelling cephalopods? ICES Journal of Marine Science. http://dx.doi.org/10.1093/icesjms/fss1167.

Xavier, J.C., Vieira, C., C., A., Cherel, Y., Hill, S., E., C., Borges, T.C., R., C., 2012b. Feeding ecology of the deep-sea shark Etmopterus pusillus in the North-east Atlantic. Scientia Marina 76, 301-310.

Xavier, J.C., Louzao, M., Thorpe, S.E., Ward, P., Hill, C., Roberts, D., Croxall, J.P., Phillips, R.A., 2013. Seasonal Changes in the Diet and Feeding Behaviour of a Top Predator Indicates a Flexible Response to Deteriorating Oceanographic Conditions. Marine Biology 160, 1597-1606.

Zapata-Guardiola, R., López-González, P., 2012. Revision and redescription of the species previously included in the genus Amphilaphis Studer and Wright in Studer, 1887 (Octocorallia: Primnoidae). Scientia Marina 76, 357-380.

Zepp, R.G., Erickson, D.J., Paul, N.D., Sulzberger, B., 2007. Interactive effects of solar UV radiation and climate change on biogeochemical cycling. Photochemical \& Photobiological Sciences 6, 286-300.

Zicus, S., Almeida, M., Edwards, K., Hik, D., Huffman, L., Kaiser, B., Malherbe, R., Munro, N., Pauls, M., Pit, M., Xavier, J.C., 2011. IPY education activities. In: Krupnik, I., Allison, I., Bell, R., Cutler, P., Hik, D., López-Martinez, J., Rachold, V., Sarukhanian, E., Summerhayes, C. (Eds.), Understanding Earth's Polar Challenges: International Polar Year 2007-2008. University of the Arctic/CCI Press, Rovaniemi, Finland, pp. 481-496. 